\title{
Relative or absolute poverty in the US and EU? \\ The battle of the rates
}

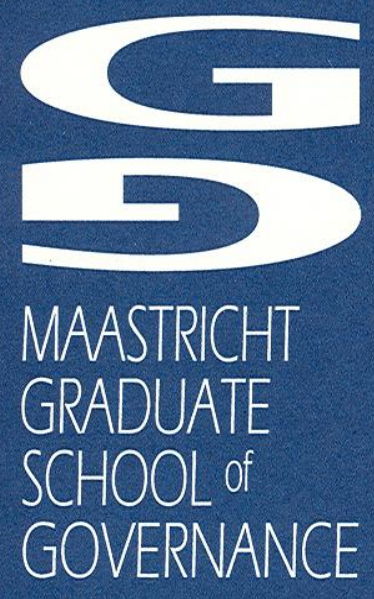

\author{
Geranda Notten \\ Chris de Neubourg
}

Working Paper

MGSoG/2007/WP001

January 2007

Maastricht University

Maastricht Graduate School of Governance 


\title{
Maastricht Graduate School of Governance
}

The 'watch dog' role of the media, the impact of migration processes, health care access for children in developing countries, mitigation of the effects of Global Warming are typical examples of governance issues - issues to be tackled at the base; issues to be solved by creating and implementing effective policy.

The Maastricht Graduate School of Governance, Maastricht University, prepares students to pave the road for innovative policy developments in Europe and the world today.

Our master's and PhD programmes train you in analysing, monitoring and evaluating public policy in order to strengthen democratic governance in domestic and international organisations. The School carefully crafts its training activities to give national and international organisations, scholars and professionals the tools needed to harness the strengths of changing organisations and solve today's challenges, and more importantly, the ones of tomorrow.

\author{
Authors \\ Geranda Notten, PhD fellow \\ Department of Economics \\ Maastricht University \\ Email: g.notten@algec.unimaas.nl \\ Prof. Dr. Chris de Neubourg \\ Maastricht School of Governance \\ Maastricht University \\ Email: Chris.deneubourg@governance.unimaas.nl
}

\author{
Mailing address \\ Universiteit Maastricht \\ Maastricht Graduate School of Governance \\ P.O. Box 616 \\ 6200 MD Maastricht \\ The Netherlands \\ Visiting address \\ Kapoenstraat 2, $6211 \mathrm{KW}$ Maastricht \\ Phone: +31 433884650 \\ Fax: +31433884864 \\ Email: info-gov@governance.unimaas.nl
}




\title{
Relative or absolute poverty in the US and EU? \\ The battle of the rates
}

\begin{abstract}
There are striking differences between relative and absolute poverty rates in the European Union and the United States. In this paper, we apply the official poverty measurement methods of the United States (absolute) and the European Union (relative) to both regions. Official poverty rates differ from other poverty statistics in the sense that they are more often used as a benchmark by policymaking and advocacy groups. In our analysis we use within and between country perspectives to explain differences in poverty levels and trends and show the impact of each of these aspects on poverty levels and over time while keeping other explanatory factors constant. Using annual data of the EU and the US from 1994 to 2000 we illustrate how some poverty differences are inherent to choosing either an absolute or a relative approach to poverty while other differences are related to more general aspects of poverty measurement. The results of our analysis suggest that governments should use both; an absolute approach that helps to identify those people who are not able to attain a minimum living standard and a relative approach to identify those whose living standard is low compared to the society they live in.
\end{abstract}

Keywords: poverty, absolute, relative, United States, European Union 


\section{Introduction ${ }^{12}$}

There are striking differences between relative and absolute poverty rates in the European Union and the United States. According to the relative poverty indicator of the EU, poverty rates are $24 \%$ in the $\mathrm{US}^{3}, 19 \%$ in the $\mathrm{UK}, 13 \%$ in Belgium but only $9 \%$ in Sweden (Eurostat, 2000-2001 ${ }^{4}$ ). However, when using the absolute poverty indicator of the US, poverty rates are $11 \%$ in the $\mathrm{US}^{5}, 9 \%$ in the UK, $4 \%$ in Belgium and $6 \%$ in Sweden in the year $2000^{6}$. The difference between relative and absolute poverty rates is rather large in the US, UK and Belgium but much smaller for Sweden. Poverty differences between countries seem smaller when an absolute poverty concept is used but now Belgium even has lower poverty rates than Sweden. Even though there are no absolute poverty rates available for the new EU Member States, we find similarly large differences in relative poverty for these countries (Eurostat, 2001). For instance, relative poverty in Lithuania is $17 \%$ but only $8 \%$ in the Czech Republic, the lowest poverty rate in the whole European Union! Moreover, differences between absolute and relative poverty rates not only influence poverty levels but also affect the poverty developments over time: since 1993 absolute poverty in Ireland declined with 19 percentage points to $11 \%$ in 2000 while relative poverty increased with 4 percentage points to $21 \%$ in the same period. How can these differences between absolute and relative poverty rates be explained? If absolute and relative poverty rates can differ so much within and between countries, what does this imply for specific groups in the population? What does it mean

\footnotetext{
${ }^{1}$ This research benefited from a grant provided by the EuroPanel Users' Network (EPUNet) that financed a research visit to CEPS/INSTEAD (Differdange, Luxembourg) as well as from a travel grant provided by the Dutch Scientific Organization (NWO) which funded a research visit to the Kennedy School of Government (Cambrige, USA).

${ }^{2}$ We would like thank our colleagues at CEPS/INSTEAD (Differdange), Kennedy School of Government (Cambridge), National Poverty Institute (Ann Arbor), Panel Study of Income Dynamics (Ann Arbor) and the participants in the conference on "New Directions in the Study of Inequality" (Princeton, April 2006) who have contributed to the progress of this research by means of their comments and suggestions. We especially want to thank Christopher Jencks, Mary Jo Bane, Erzo Luttmer and Gary Sandefur for their constructive suggestions.

${ }^{3}$ The relative poverty rate for the US is based on own calculations.

${ }^{4}$ At-risk-of-poverty rate after social transfers available on http://epp.eurostat.ec.europa.eu/ (retrieved December 2006).

${ }^{5}$ Historical poverty tables on the website of the Bureau of Census http://www.census.gov/hhes/www/poverty/poverty.html (retrieved December 2006).

${ }^{6}$ The absolute poverty rates for the European countries are based on own calculations.
} 
when children in some country have a high absolute poverty risk while at the same time, they are not more likely to be poorer than other groups in relative terms?

Moreover, although many countries annually report (semi-) official poverty statistics, some use relative poverty statistics while other use an absolute approach. These statistics are used by governments to evaluate and/or adjust social and economic policies, politicians and interest groups quote them to argue their case and the publication of the results receives considerable media coverage every year. The absolute and relative poverty rates mentioned above are calculated using the official measurement methods of the European Union and the United States. The official USA poverty measurement methodology was developed by Molly Orshansky in the 1960s and is based on an absolute concept of poverty. Albeit regularly criticized and by times hotly debated, the Census Bureau still uses this method for its annual poverty assessments. At the start of this millennium, the Member States of the EU agreed to use a common set of poverty and social exclusion indicators also called the 'Laeken' indicators. The subset of these indicators that is concerned with financial poverty in EU Member States uses a relative concept of poverty.

These "official" poverty statistics influence the policy arena in the US and the EU. In the US, household's eligibility to social assistance programs such as food stamps and family allowances (partly) depends on whether their income falls below some percentage of the official poverty line. For example, to be eligible for food stamps households must have gross incomes below 130 percent of the poverty line. In addition, because the federal food stamp program funds 100 percent of the benefits, it also redistributes federal tax funds unevenly across states. In the European Union, policies to combat poverty and social exclusion are first and foremost the responsibility of national governments. Nevertheless, all Member States agreed to use the Laeken indicators to monitor progress on their National Action Plans on Social Inclusion (NAPincl). ${ }^{7}$ Some Member States specify explicit poverty targets in their action plans while others do not (Atkinson et al,

\footnotetext{
${ }^{7}$ Each country can additionally define their own indicators to supplement the common Laeken indicators (so-called third level indicators) (Atkinson et al 2002).
} 
2002). In any case, the Laeken indicators facilitate inter-Member State comparisons in terms of poverty and social exclusion. Albeit at a lower scale than in the US, redistribution between Member States also takes place at a European level through the European Social Fund (ESF) and the European Regional Development Fund (ERDF). These funds are aimed at socially excluded groups or the development of disadvantaged regions. Although access to these funds is not based on "scores" of the Laeken indicators, funding proposals as well as project evaluations will increasingly use Laeken indicators to argue their case. ${ }^{8}$

Given the importance of these official poverty statistics for policymaking and advocacy groups, how can we explain differences between absolute and relative poverty rates? Are they the result of conceptual and methodological differences in the measurement of absolute and relative poverty or do they simply reflect differences in social and economic policy regimes? In this paper we focus on the underlying technical reasons for differences between relative and absolute poverty rates. We use the official poverty measurement methodologies of the European Union and the United States to illustrate differences between absolute and relative poverty rates and apply both measurement methods on the United States and the old EU Member States (EU-15). We show the impact of each technical reason on poverty levels and poverty trends while keeping other explanatory aspects constant. From an academic point of view, this exercise is relevant because it enhances our understanding of how poverty statistics are influenced by methodological decisions. Our analysis shows how some poverty differences are inherent to choosing either an absolute or a relative approach to poverty while other differences are related to more general aspects of poverty measurement. In short, we explain and illustrate how differences in inequality and changes in inequality over time affect absolute and relative poverty levels and poverty trends. Additionally, we investigate the impact of Purchasing Power Parity rates (PPP) and year to year updating methods of poverty lines on poverty. Finally, even though equivalence scales are used in every poverty approach, we show that

\footnotetext{
${ }^{8}$ For instance, during the second European Round Table on Poverty and Social Exclusion held in Turin on 16-17 October 2003, a workshop was organized to examine the ways in which Member States have made, or plan to make, use of Structural Funds to support measures to combat poverty and social exclusion, as identified in their NAP-incl for 2003-2005.
} 
equivalence scales impact absolute and relative poverty rates differently and explain how this result comes about.

Does it make more sense to use an absolute or a relative approach for (semi-) official poverty statistics? The results of our analysis suggest that governments should use both; an absolute approach that helps to identify those people who are not able to attain a minimum living standard and a relative approach to identify those whose living standard is low compared to the society they live in. ${ }^{9}$ Even though the countries we study here have high income levels as compared to the rest of the world, special attention should be given to those people that are unable to generate the resources to cover the basic cost of living in their society. On the other hand, concerns about the distribution of welfare, (un)equal sharing the proceeds from economic development and/or social cohesion underline the relevance of a relative approach to poverty. This paper is structured as follows; in section 2 we define the poverty concepts and notation used in our analysis; section 3 explains the official poverty methods of the EU and US in more detail; section 4 describes the data and discusses the steps we undertook to make the data comparable; in section 5 we analyze the technical aspects which explain differences between relative and absolute poverty rates and show the poverty impact of each reason separately; section 6 concludes.

\section{Poverty measurement: concepts and definitions}

There exists an extensive literature that elaborates at length on the wide range of issues involved in making poverty comparisons (see for instance Ravallion (1992) or Duclos and Araar (2006)). Although we certainly discuss some of the arguments put forward in this literature it is beyond the scope of this paper to give a comprehensive review. In this section we shortly explain the general concepts and notation that we use in our analysis.

\footnotetext{
${ }^{9}$ We do not argue that the official poverty methodology currently used in the US is the best option in this respect. The US method could be improved in many ways. For a comprehensive overview on its problems and how the methodology could be improved see Citro and Michael (1995) "Measuring Poverty: a New Approach".
} 
Key concepts involved in any poverty analysis are the welfare indicator, poverty line, unit of analysis, equivalence scales and poverty measure. The welfare indicator is a measure for the dimension of well being (or deprivation) under study. The measurement methods that we compare in this study are concerned with the economic well being of their citizens and approximate this welfare dimension by measuring income. ${ }^{10}$ The poverty line represents the threshold value of the welfare indicator which in turn determines the poverty status. When income is below the poverty line, the unit of analysis is considered 'poor' and otherwise it is 'not poor'. With income poverty, the household is often the unit of analysis because it is at this level that resource sharing, including income, typically takes place. Equivalence scales are used to take differences between households into account because these differences ceteris paribus also generate differences in well being. Equivalence scales can adjust for differences in food requirements between age and gender groups. They can also take into account that larger households typically have lower expenditures per member because they share resources (i.e. house, car) or because they can buy larger quantities of food for a lower unit price. These equivalence scales either correct the welfare indicator to an adult equivalent level, or adjust the poverty line to fit the characteristics of the household. Finally, a poverty measure aggregates the poverty result from the unit of analysis to the population. ${ }^{11}$ A widely used group of poverty measures is the Foster Greer Thorbecke (FGT) class of decomposable poverty measures which reflect the percentage of poor people as well as the depth and severity of poverty experienced (Foster et al, 1984). In this study we mainly use the percentage of poor people, also called headcount or poverty incidence.

\footnotetext{
${ }^{10}$ Income, by far, is the most important source for financing consumption in developed economies, thereby making it a logical indicator for current living standards. Nevertheless, measuring income has a number of drawbacks. One drawback of this indicator is that it labels households that are financing current consumption from assets (such as savings or loans) as 'poor', while their stock of assets may be more than sufficient to finance an acceptable level of economic well-being. Similarly, it can also label households that are financing large debt repayments from current income as 'non poor'.

${ }^{11}$ Note that, although the household is the unit of analysis, aggregate (income) poverty measures are usually calculated by counting individuals. Thus, if household income is below the poverty line, the aggregate poverty measure counts all household members instead of a single household.
} 
Summarizing the above discussion more formally, we can denote adult equivalent income with y and let $\mathrm{F}(\mathrm{y})$ represent cumulative distribution function which gives the probability of observing someone with an income less than $y$.

$$
F(y)=\int_{0}^{y} f(y) d y
$$

where $\mathrm{f}(\mathrm{y})$ is the probability of observing income with a value of $\mathrm{y}$. The poverty line $\mathrm{z}$ can take the values $0 \leq \mathrm{z} \leq \mathrm{y}$. The headcount index can be described as:

$$
H=F(z)=\int_{0}^{z} f(y) d y
$$

The poverty line can be determined with respect to some objective benchmark such as the cost to fulfil basic needs (food, shelter, clothing etc.). It can also be set in relation to the typical living standard in a society. As commonly denoted in the poverty literature, we call the first an 'absolute' method while we label the latter as 'relative'. Authors such as Boyle (1999) and Ravallion (1992) have argued that this terminology is misleading: the term absolute poverty suggests that the approach taken is objective and positive but every application of this concept involves some normative judgement about insufficiency and/or benchmarking with society. Therefore, "an absolute poverty line is best thought of as one which is fixed in terms of living standards and fixed over the entire domain of poverty comparison; a relative poverty line, by contrast, varies over that domain and is higher the higher the average standard of living" (Ravallion, 1994, p.30). In formal notation, an absolute poverty line is determined by:

$z_{a}=f(x)$

where $f(x)$ represents the value of attaining some objective benchmark $x$. A relative poverty line is often determined by a fraction $(\mathrm{k})$ of some moment $(\mathrm{m})$ of the income distribution $\mathrm{f}(\mathrm{y})$ :

$\mathrm{z}_{\mathrm{r}}=\mathrm{k} *[\mathrm{~m} \mid \mathrm{f}(\mathrm{y})]$ 
where $0<\mathrm{k}<1$. The mean or median of the income distribution are typically the moments that are used to determine a relative poverty threshold.

\section{Official poverty measurement methods in the US and EU}

The official poverty methodology used in the United States is based on an absolute concept of poverty while the European method uses a relative poverty concept. This section shortly discusses the origin of both methods as well as their main characteristics.

Poverty measurement in the USA; the Orshansky thresholds

The US poverty thresholds were developed in the 1960s by Molly Orshansky, an economist working for the Social Security Administration. ${ }^{12}$ In that time there was no generally accepted standard of basic needs that could be used to determine a minimum consumption basket. The Agriculture Department, however, had defined food plans which measured the costs of food for various budgets ranging from 'liberal', 'moderate', 'low-cost' to 'economy'. Orshansky used the lowest food plans 'low-cost' and 'economy', were the costs of 'economy' were about 75-80\% of the 'low-cost' plan, to develop two sets of thresholds. The current official poverty estimates are based on the thresholds of the 'economy' food plan which was designed for families under economic stress.

To obtain a poverty line that also included the costs of non-food consumption, Orshansky used the 1955 Household Food Consumption Survey to estimate the average share of food expenditures in total income for families of three or more persons. ${ }^{13}$ To obtain the overall consumption threshold, the cost of the food budget was multiplied by the reciprocal of the food share (i.e. the food-ratio method). The threshold varies with

\footnotetext{
${ }^{12}$ This description of the Orshansky methodology is largely based on the information provided on the website of the Bureau of Census (http://www.census.gov/hhes/www/poverty/poverty.html). Especially helpful was the online paper of G. Fisher on the Development of the Orshansky poverty thresholds (Fisher, 1992).

${ }^{13}$ Orshansky found that the average share of food expenditures was about one third of family income. Also note that this is the average food share of the total population of families and not low-income families.
} 
demographic composition of families. Although there have been some minor changes in the methodology over time, the poverty thresholds currently used are essentially the same as those developed in the 1960s. Currently, there are 48 poverty lines depending on family size and the age of household members. These thresholds are annually adjusted for inflation. ${ }^{14}$ Every year, an inflation adjustment is made using the consumer price index for urban consumers (CPI-U), which is the same for the whole USA.

The official poverty rates are annually estimated by the Bureau of Census using the March Supplement of the Current Population Survey (CPS). The poverty status of a family is obtained by comparing its gross annual income to the poverty threshold of that family type. The welfare indicator only includes 'money' income i.e. earnings and money transfers. Thus in-kind transfers such as food stamps or the consumption of public goods are not included. Housing allowances and capital gains (or losses) are also not included in the income aggregate. Note that the demographic characteristics determining the poverty line are based on the current household situation while the welfare indicator reflects total family income of the previous (tax) year.

\section{Poverty measurement in the EU: the Laeken indicators}

On the Nice summit in 2001, the EU Member States decided to combat poverty and social exclusion by means of the open method of coordination. This method "involves fixing guidelines for the Union, establishing quantitative and qualitative indicators to be applied in each member state, and periodic monitoring" (Atkinson et al, 2002, p. 5). The design and implementation of policies to fight poverty and social exclusion, however, remains predominantly the responsibility of the Member States. To monitor progress in these areas, a set of common statistical indicators was developed. Named after the Laeken European Council who endorsed the indicators in 2001, these 'Laeken indicators' cover four dimensions of social inclusion; financial poverty, employment, health and education.

\footnotetext{
${ }^{14}$ The thresholds are available for each year on the website of the Bureau of Census on www.census.gov/hhes/www/poverty/threshld.
} 
In this paper, we use the subset of the Laeken indicators that is concerned with financial poverty.

Most of the so-called Laeken "At-risk-of-poverty" indicators are based on a relative poverty line that is set at $60 \%$ of national median adult equivalent income (Eurostat, 2003). The welfare indicator is based on annual net household income and includes the earnings and transfers received by the household in the year previous to the survey. To control for the demographic composition of the household and economies of scale, household income is adjusted using the modified OECD equivalence scales. ${ }^{15}$ When adult equivalent household income falls below $60 \%$ of (national) median adult equivalent income, all of the household members are poor.

\section{Data and methodology ${ }^{16}$}

The USA and EU have developed distinctive approaches to poverty measurement. The task of applying both approaches on each country / group of countries while ensuring comparability of the results is not an easy, nor a trivial one. The main challenge lies in the construction of comparable welfare indicators as well as poverty thresholds. This section describes the data we use and explains the steps we take to obtain comparable welfare indicators and poverty lines.

\section{Data}

For the European Union we use the European Community Household Panel (ECHP). ${ }^{17}$ The ECHP is a survey on households' income and living conditions carried out in 8 waves from 1994 until 2001 and includes the so-called EU-15 countries. ${ }^{18}{ }^{19}$ The data

\footnotetext{
${ }^{15}$ The modified OECD equivalence scale gives a weight of 1 to the first adult in the household, a weight of 0.5 to other members aged over 14 years and a weight of 0.3 for children under age 14 .

${ }^{16}$ We have also documented these issues more in detail in an appendix which can be obtained from Geranda Notten (g.notten@algec.unimaas.nl).

${ }^{17}$ For more information we refer to the official ECHP documentation as well as the ECHP website http://forum.europa.eu.int/irc/dsis/echpanel/info/data/information.html.

${ }^{18}$ Austria, Belgium, Denmark, Finland, France, Germany, Greece, Ireland, Italy, Luxembourg, The Netherlands, Portugal, Sweden and United Kingdom.
} 
provide cross-section and longitudinal information on household and individual level on topics such as income, education, housing, health and social relations. Comparability of the ECHP data is achieved through common survey structure and procedures, common standards on sampling requirements and where possible on data processing and statistical analysis as well as the use of a 'blue-print' questionnaire used as point of departure for the national surveys. ${ }^{20} 21$ The European statistics office, Eurostat, also uses the ECHP to calculate the Laeken poverty indicators.

For the United States, we use data from the Panel Study of Income Dynamics (PSID) from 1994-2001. The PSID is a nationally representative longitudinal survey containing information on individual and family level on economic and demographic topics such as income, employment, family composition and residential location. Started as an annual survey in 1968, the PSID became a biennial survey since $1997 .^{22}$ The PSID is available in two formats; the original PSID and the so-called Cross-National Equivalent Files (CNEF) which contains equivalently defined variables for the panel surveys of four countries (Germany, United Kingdom, Canada and United States). ${ }^{23}$ The advantage of the CNEF is that the PSID variables are harmonized with two datasets that are also the basis for the ECHP, which facilitates the construction of comparable welfare indicators. We mainly use the CNEF, but have also supplemented the data with variables from the PSID. ${ }^{24} 25$

\footnotetext{
${ }^{19}$ Most of the countries are included in every wave except for Austria (1995-2001), Finland (1996-2001) and Sweden (1997-2001).

${ }^{20}$ Albeit harmonized, cross-country comparability of the ECHP data is not perfect. Some variables are not available for every country. In some cases this is because this information was not collected and in other cases information is confidential. More detailed information on missing information can be found in the extensive variable description (Eurostat, 2003).

${ }^{21}$ ECHP data from Sweden, Denmark and Finland are based on statistical registers drawn from administrative records. Comparison of Finnish household survey data with the Finnish ECHP data based on statistical registers shows considerable higher income levels for the lowest two income deciles using survey data. As the other ECHP countries use survey data this affects cross-country rankings of poverty levels (Rendtel et al, 2004).

${ }^{22}$ This implies that we cannot compare our results for 1998 and 2000.

${ }^{23}$ For more information we refer to the PSID website (http://psidonline.isr.umich.edu/) and the CNEF website (http://www.human.cornell.edu/che/PAM/Research/Centers-Programs/German-Panel/CrossNational-Equivalent-File_CNEF.cfm).

${ }^{24}$ The CNEF does not include all information of the PSID but it is relatively easy to merge information from the PSID with the CNEF. We used information on heating subsidies, food stamps and tenure from the PSID.

${ }^{25}$ The official US poverty statistics are calculated using the March Supplement of the Current Population Survey (CPS).
} 


\section{Income}

Both the EU and US use income as welfare indicator for the poverty analyses. However, in the US gross income is used while the EU uses disposable income. As we are interested in welfare outcomes, we prefer to use disposable income because disposable income better reflects the funds that a household can spend on consumption.

Total disposable household income in the ECHP is defined according to the Laeken methodology. This variable includes wage and salary earnings, net earnings from selfemployment, capital income, property and rental income, private transfers and social transfers specified for a range of typical social programs (unemployment, various pension types, sickness and invalidity, family allowances, education and social assistance). It does not include the monetary value of in-kind transfers or imputations for house ownership. Because the income variables in the ECHP are constructed using the same (or similar) methodology for all Member States, our main concern is the construction of a comparable welfare indicator in the US data.

One of the advantages of using the CNEF is that these data include estimates of households' tax burdens while the PSID does not. The CNEF also includes disaggregated income sources such as labour income, asset income, public and private transfers, social security pensions and private pensions. Households' federal and state income tax burden have been imputed using the NBER TAXSIM model and PSID data while the burden of payroll taxes have been estimated using the tax rates reported by the Social Security Bulletin. We can therefore construct an estimate of household disposable income for the United States that is very similar to the one used in the ECHP. Below we discuss a number of comparability issues in detail.

Firstly, we compared the PSID questionnaires and the CNEF algorithms with those used in the ECHP and found that the PSID takes similar income sources into account as the ECHP. The level of detail in the PSID questionnaires is somewhat higher for sources of 
asset and entrepreneurial income and we found different algorithms for the calculation of entrepreneurial income. It is therefore possible that the PSID values for these variables are somewhat different than if the ECHP methodology would have been applied. ${ }^{26}$ This also holds for education allowances and/or stipends for which the PSID does not include any specific questions. ${ }^{27}$ The CNEF does not include the value of housing and heating subsidies but information on heating subsidies is available in the PSID. We retrieved this information and added it to households' income.

The value of food stamps is included in CNEF transfer income while the ECHP labels such benefits as in-kind and does not include them. We think that the value of received food stamps should be included in our welfare indicator for two reasons. Firstly, the food stamp program is one of the main programs that targets poor households in the US; not including the value of these benefits would ignore this important poverty reduction effort. Secondly, food stamp benefits can be considered as 'near money' because they are issued in the form of an electronic debit card that can be used to purchase food items in a range of supermarkets.

The ECHP income data are collected with the intention to obtain an estimate of households' disposable income (except Finland and France which collect gross income). In addition, the ECHP collects information on gross income (individual, monthly) which is used to estimate the tax burden for each household. The PSID however, collects gross income and does not include an estimate for households' tax burden. Even though the CNEF provides an estimate of households' tax burdens, it is estimated using secondary information sources and with a different methodology than the estimate in the ECHP. ${ }^{28}$

\footnotetext{
${ }^{26}$ A higher level of detail in questionnaires typically increases reported income from these sources. The calculation of entrepreneurial income of the PSID also includes certain aspects of asset wage income which can also be negative. A priori, it is not clear what impact this has on the values of these income sources. For more detailed information on the algorithm we refer to the excellent codebooks of the CNEF.

${ }^{27}$ If reported, such benefits are included in the miscellaneous transfer category.

${ }^{28}$ Before 1992, the PSID included an estimate of the tax burden. Butrica and Burkhauser (1997) show in a comparison between the TAXSIM model and the PSID tax burdens that the mean and median tax burdens are very similar but that the TAXSIM model overestimates the tax burden at the higher end of the income distribution. This is mainly caused by the basing the calculations on the standard deduction while more affluent households typically have a higher deduction because they itemize the deductions. The resulting
} 
One aspect that can influence the US poverty estimates is that the model used for imputing tax burdens incorporates the higher deductions for low income families with children (Earned Income Tax Credit (EITC)) while eligible households do not always apply for it (resulting in an upward bias of poverty).

Perfect comparability cannot be achieved. In many cases the information needed to estimate the potential impact of differences in algorithms and other data issues is not available. Where possible we have made adjustments to the CNEF data that enhance comparability with the ECHP but, as indicated in the above discussion, we could not account for all methodological differences. ${ }^{29}$ Nevertheless, we think that the ECHP and the PSID/CNEF have been designed to take into account those income sources that are relevant in the countries where the survey is held; in kind social assistance plays a much larger role in the US than it does in continental Europe, education benefits and housing subsidies are more prevalent in European welfare states than they are in the US. These differences are also relevant for understanding differences in poverty and should thus be incorporated in the analysis.

\section{Poverty lines}

We retrieved the US poverty thresholds for each year from the website of the Bureau of Census and converted the 1993 dollar thresholds to the Member States' currencies using 1993 Purchasing Power Parity (PPP) indices. After the conversion of the US thresholds to national purchasing power values, we updated the thresholds to other years using national consumer price indices. In section 5.1.2 we further discuss the use of PPP indices for this type of analysis. The national Laeken poverty lines are set each year using the adult equivalent income distribution in each survey wave.

underestimation of disposable income is not so problematic for our poverty analysis because it takes place at the higher end of the income distribution.

${ }^{29}$ For instance, when income from entrepreneurial activities is negative, the ECHP sets the observed income from this source to zero. As a result there are no negative observations in the ECHP for this income source while these are present in the PSID and the CNEF. To enhance comparability we have therefore decided to set any negative values from labor earnings to zero in the CNEF. Comparing poverty headcounts with and without the adjustment suggests that the impact of this adjustment on poverty statistics is negligible. 


\section{Equivalence scales}

Both datasets contain all necessary information to construct modified OECD-equivalence scales and to establish the characteristics of the household needed to match a household with its respective US poverty line.

Tables A1-A3 in the appendix summarize the number of households and individuals as well as the mean (annual) per capita and adult equivalent income levels by country and survey round. A final issue to note is that while the survey data have been collected from 1994-2001, the income variables reflect household income in the year previous to the survey (thus, from 1993-2000). The information on the household size and composition, which is also used for the determination of the poverty rate, is based on the survey year. We (arbitrarily) decided that the calculated poverty rates reflect the period 1993-2000.

\section{Dissecting the official poverty methodologies of the EU and US: what's in a number?}

Using the methodology explained above we have calculated the official EU (Laeken relative) and US (Orshansky - absolute) poverty rates for each country over time. Figure 1 shows that there are both level and trend differences in official poverty rates and that the experience differs between countries. Ireland shows opposing trends in poverty rates; using the US method poverty declines while using the EU method poverty increases. For Germany, Netherlands, Belgium and the United States both poverty indicators follow the same trend. In most countries, the Laeken poverty rates are higher than the Orshansky poverty rates but this does not hold for Portugal, Greece and Spain. The difference between Orshansky and Laeken poverty rates is larger in countries like the United States and Luxembourg but considerably smaller in the Netherlands, Denmark and Sweden. In this section we explain and empirically illustrate the impact of methodological decisions in relative and absolute poverty measurement methods. 
We focus on three dimensions: differences in poverty levels, poverty trends and poverty risk for particular population groups. Within each of these dimensions we first recognize a number of underlying causes and then illustrate the effect of this cause on the official poverty statistics while keeping everything else equal. Firstly, we explain how difference sin income inequality and the use of purchasing power parity rates to convert US thresholds affects absolute and relative poverty levels. Secondly, we analyze how differences in year to year updating of poverty lines and changes in income inequality influence absolute and relative poverty trends. Finally, using the equivalence scales of the Laeken and Orshansky poverty measurement approaches as an example, we explain how equivalence weighting affect absolute and relative poverty rates differently (overall poverty rates as well as those of particular population groups).

\subsection{Differences in poverty levels}

There are two important reasons why the official US and EU poverty levels differ within and between countries, namely differences in inequality (i.e. the shape of the welfare distribution) and the use of Purchasing Power Parity (PPP) rates to convert the US poverty lines to country specific thresholds. Differences in income inequality affect the level of relative (Laeken) poverty lines but not of absolute (Orshansky) poverty lines. Differences in cost of living affect the absolute poverty levels.

\subsubsection{Inequality in welfare}

Relative poverty rates depend on the degree of welfare inequality in a society because the threshold is set relative to the welfare of a 'typical' resident in that society. The underlying rationales for using a relative approach to poverty measurement are either based on some kind of value judgment (an unequal distribution of welfare is unfair) or a 
Figure 1: Poverty incidence (in \% of individuals over the period 1993-2000)

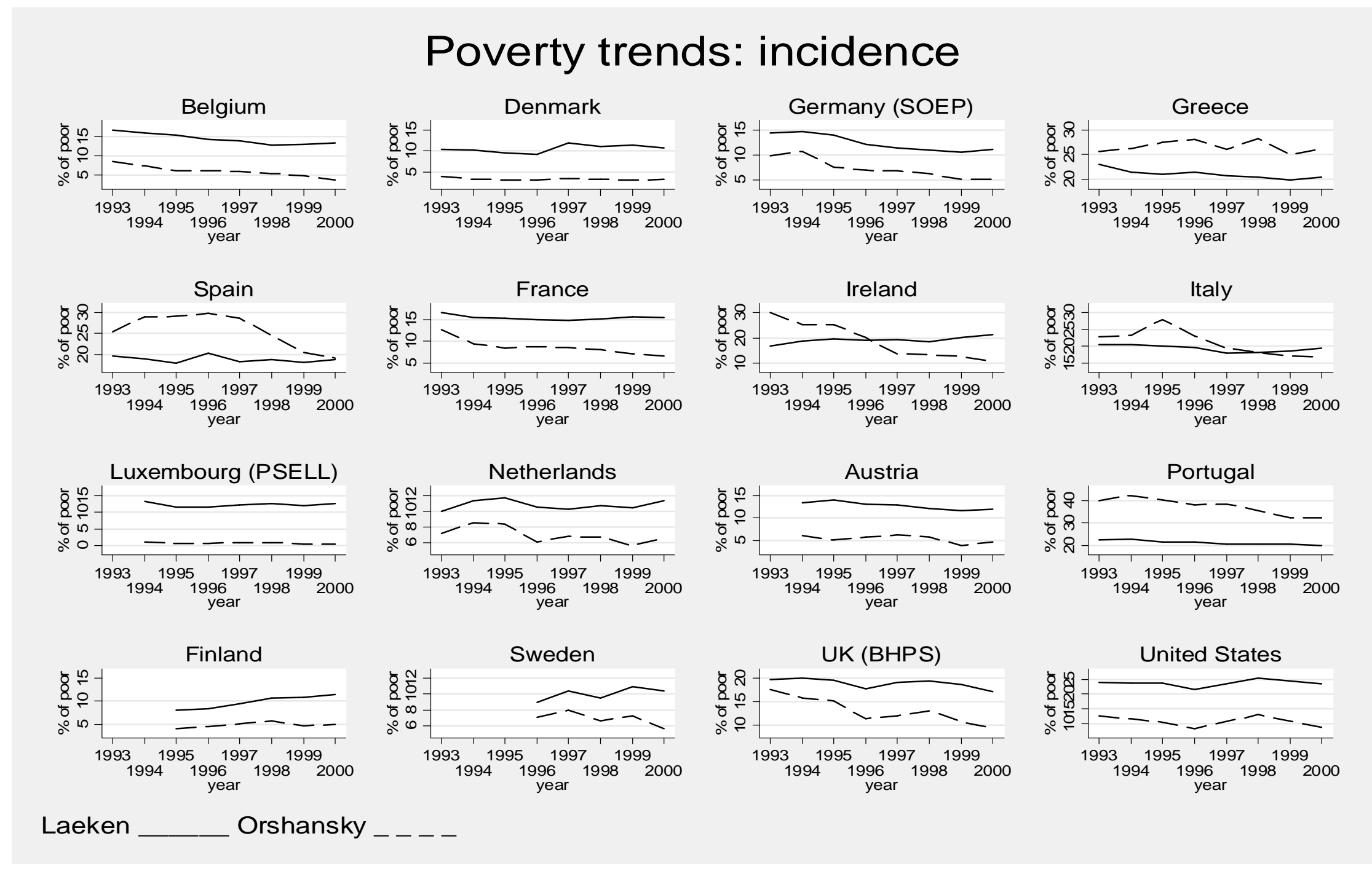


societal preference (societies prefer more equality above less / are inequality averse). Therefore, a logical requirement for any given relative poverty method would be that it yields higher poverty in a country with more inequality, than in a country with less inequality. But with poverty measurement the concern is not about inequality as such, but about the welfare inequalities between the typical resident and those residents that have fewer resources than this person.

This implies that differences in relative poverty rates between countries (or any other group) arise because in some countries there is more dispersion at the lower/left part of the welfare distribution than in other. In the Laeken methodology, the typical resident is the median (the middle person) and the poverty line is set at $60 \%$ of the income earned by the median person. Thus, the concept of inequality used in the Laeken methodology is very narrow, and it is relatively easy to construct examples that would conflict with the above requirement. ${ }^{30}$ When using the Laeken methodology (or any similar approach), higher inequality leads to higher relative poverty rates; but only under specific conditions. This becomes clear when we try to state these conditions more formally. Firstly, we shift our focus from the whole income distribution to its left part only. Let $F_{m}(y)$ represent the cumulative income distribution summed until the income of the typical resident, $y(m)$ :

$$
F_{m}(y)=\int_{0}^{y(m)} f(y) d y
$$

where $\mathrm{f}(\mathrm{y})$ is rescaled by $\mathrm{y}(\mathrm{m})$ such that $0 \leq \mathrm{y} \leq 100$ and $\mathrm{y}(\mathrm{m})=100 .^{31}$ The relative poverty line $(\mathrm{z})$ is determined as a constant fraction of the income of the typical resident (see Equation 4). Now take two countries, whose cumulative income distributions are indicated with $F^{A}(y)$ and $F^{B}(y)$. Country A only has higher relative poverty rates than country B when its cumulative income distribution evaluated at the poverty line, z, lies above that of country B.

\footnotetext{
${ }^{30}$ For instance, country A and B have exactly the same welfare distribution at and below the 'typical' resident, but above the welfare in A is distributed more equally than in country B. Country B has higher inequality than country A but any relative poverty methodology will yield the same poverty rate for country $\mathrm{A}$ and $\mathrm{B}$.

${ }^{31}$ The rescaling is done because it allows us to compare the income distributions of different countries while focusing on the dispersion of these income distributions.
} 
In other words, there is more income dispersion below the poverty line in country A than in country B. This is a very narrow concept of inequality because country B could have higher relative poverty rates if we use other fractions $(\mathrm{k})$ of the income of the typical resident or if we take another moment to select the typical resident. ${ }^{32}$ Apart from these robustness failures, the relative poverty rates can also contradict with other inequality measures.

Thus, countries with higher income dispersion below the poverty line have higher relative poverty rates. In addition, as absolute thresholds do not take distributional characteristics into account, countries with higher income dispersion are more likely to have larger differences between absolute and relative poverty rates. ${ }^{33}$ Especially when the absolute threshold is based on some assessment of the minimum amount of resources needed to cover the basic cost of living in a country, large differences between absolute and relative poverty levels can arise. We now illustrate the income dispersion within the US and the EU Member States in a number of ways and examine to what extent they are consistent with poverty outcomes.

Because the Laeken methodology determines the relative poverty line using the median as a benchmark, we are interested in the income dispersion at the lower half of the income distribution. Figure 2 shows boxplots for each country using the 2000 income distribution. ${ }^{34}$ The boxplots are drawn using only the observations in the lower half of the

\footnotetext{
${ }^{32}$ Only when $F_{m}^{A}(y)>F_{m}^{B}(y)$ for all incomes below y(m), country A always has higher relative poverty rates then country B.

${ }^{33}$ Moreover, in countries with a high dispersion of incomes around the poverty line, poverty rates are very sensitive to the locus of the poverty line; a slight change in the level of the poverty line can have a large impact on the poverty rates (i.e. the poverty elasticity is high).

${ }^{34}$ Boxplots are a means to graphically summarize a number of key characteristics of a distribution. The box includes all observations within the $25^{\text {th }}$ and $75^{\text {th }}$ percentile and the vertical line within the box indicates the $50^{\text {th }}$ percentile (i.e. the median). The larger the spread of a distribution, the wider the box is. The lines outside the box are called 'whiskers', the end of the whisker does not necessarily indicate the lowest or highest observation. Outliers are located outside the whiskers.
} 
income distribution. We have rescaled income by setting median income in each country to 100 (in this way the horizontal axis is the same for all countries). Thus, the wider the box, the larger is the income dispersion below the median. The vertical line in the figure at $60 \%$ indicates the locus of the Laeken threshold. All observations falling below this line are in relative poverty. ${ }^{35}$ We can see that countries with higher dispersion below the median also have higher relative poverty rates (United States, United Kingdom, Ireland, Portugal, Italy, Greece, and Spain). The position of the box also matters, if the box of the United States would lie more to the right relative poverty rates would be lower than in the

Figure 2: Dispersion of income below median (2000)

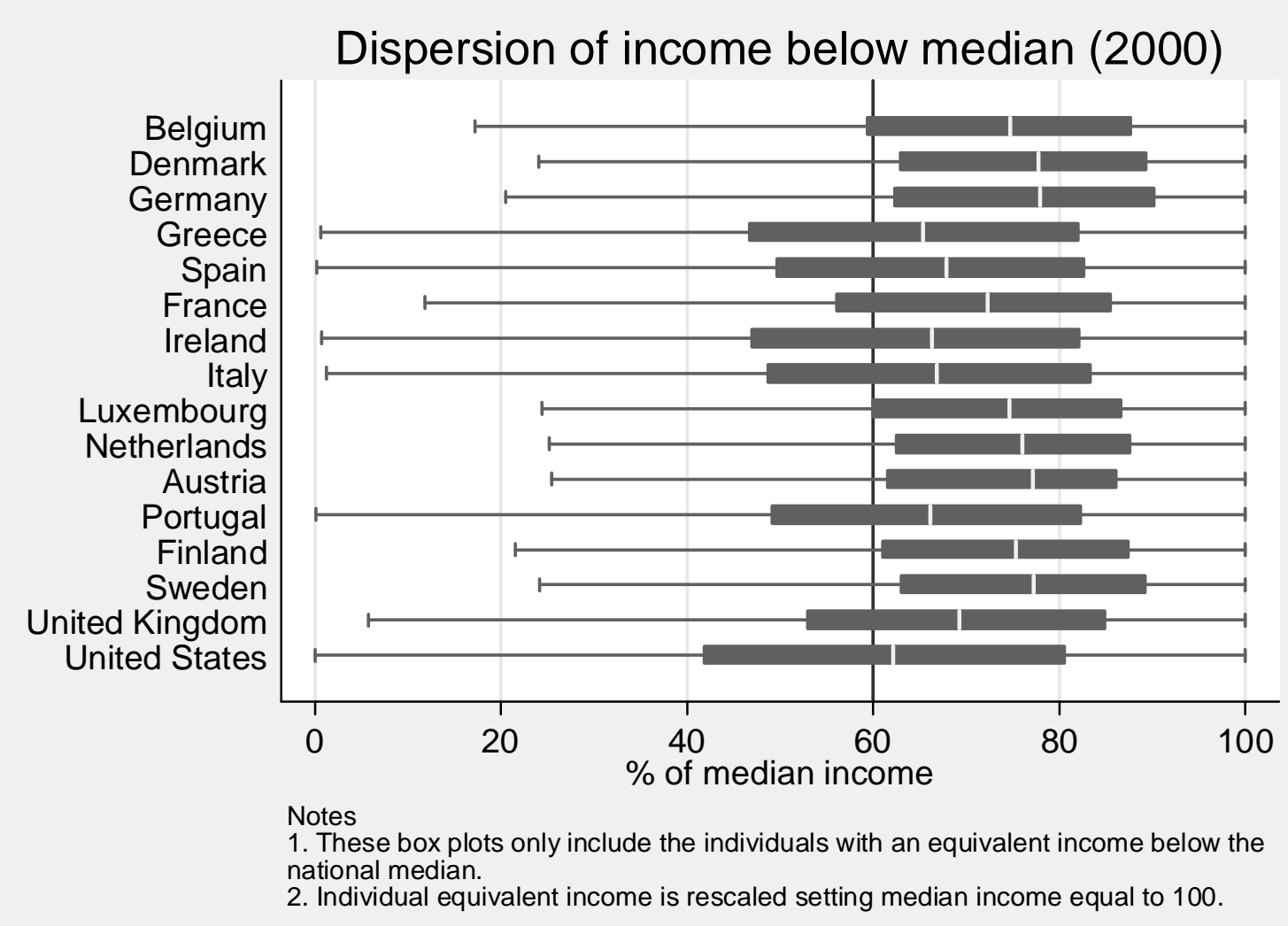

\footnotetext{
${ }^{35}$ The relative poverty rate can also be approximately read from the figure. Take for instance Luxembourg. For this country the $60 \%$ of median income line coincides with the $25^{\mathrm{th}}$ percentile of the income distribution thus implying a poverty rate of $12.5 \%$.
} 
current situation. This underlines the argument that relative poverty methods use a narrow concept of inequality; it is the degree of income dispersion below the poverty line that ultimately determines the poverty rate

Table 1 : Indicators of income dispersion and poverty rates (2000)

\begin{tabular}{|c|c|c|c|c|c|c|c|}
\hline & $\begin{array}{c}\mathbf{y}(\mathbf{m}) \\
\text { (in Euro) }\end{array}$ & $\begin{array}{c}\text { Gini of } \\
F(y)\end{array}$ & $\begin{array}{l}\text { Gini of } \\
F_{m}(y)\end{array}$ & $\mathbf{z}_{\mathbf{r}} / \mathbf{y}(\mathbf{m})$ & $z_{a} / y(m)$ & $\mathbf{H}_{\mathbf{r}}$ & $\mathbf{H}_{\mathbf{a}}$ \\
\hline Belgium & 15,493 & 0.280 & 0.144 & 0.60 & 0.51 & 13.3 & 3.6 \\
\hline Denmark & 20,620 & 0.216 & 0.139 & 0.60 & 0.50 & 10.8 & 3.4 \\
\hline Germany & 15,760 & 0.253 & 0.142 & 0.60 & 0.54 & 11.1 & 5.1 \\
\hline Greece & 7,119 & 0.328 & 0.200 & 0.60 & 0.80 & 20.5 & 26.1 \\
\hline Spain & 9,034 & 0.327 & 0.191 & 0.60 & 0.70 & 18.8 & 19.1 \\
\hline France & 14,914 & 0.270 & 0.160 & 0.60 & 0.54 & 15.4 & 6.5 \\
\hline Ireland & 14,271 & 0.288 & 0.182 & 0.60 & 0.51 & 21.4 & 10.6 \\
\hline Italy & 10,401 & 0.294 & 0.201 & 0.60 & 0.66 & 19.3 & 16.7 \\
\hline Luxembourg & 23,114 & 0.265 & 0.136 & 0.60 & 0.36 & 12.5 & 0.6 \\
\hline Netherlands & 13,820 & 0.261 & 0.150 & 0.60 & 0.57 & 11.3 & 6.6 \\
\hline Austria & 15,292 & 0.242 & 0.145 & 0.60 & 0.52 & 11.9 & 4.8 \\
\hline Portugal & 5,983 & 0.369 & 0.187 & 0.60 & 0.91 & 20.1 & 32.2 \\
\hline Finland & 14,866 & 0.244 & 0.142 & 0.60 & 0.53 & 11.4 & 4.9 \\
\hline Sweden & 16,353 & 0.242 & 0.142 & 0.60 & 0.54 & 10.4 & 5.7 \\
\hline United Kingdom & 17,724 & 0.306 & 0.179 & 0.60 & 0.52 & 17.1 & 9.3 \\
\hline United States & 24,785 & 0.394 & 0.228 & 0.60 & 0.39 & 23.5 & 8.8 \\
\hline
\end{tabular}

Table 1 relates the absolute (Orshansky) and relative (Laeken) poverty rates to a number of other indicators of dispersion. The second column displays the national median incomes expressed in Euro's (using average annual exchange rate in 2000). The third and fourth column show the Gini indices calculated for the whole distribution and for the lower half of the distribution. We can see that the countries with a higher Gini for the whole distribution also have a higher Gini for the lower part of the distribution.

Empirically, countries with higher relative poverty rates also score high on this inequality measure. The other columns show the ratio of both poverty lines over median income as well as the headcount poverty rates. Clearly, differences between the income levels at which the absolute and relative poverty lines are set also affects the discrepancy between absolute and relative poverty rates. The extremely large difference between absolute and 
relative poverty rates in the United States has its origins not only in the high dispersion of incomes below the poverty line, but also in the different position of the thresholds; the absolute threshold is much lower than the relative threshold.

\subsubsection{Cost of living}

The countries which we use in our poverty analysis have different currencies and different price levels. International poverty comparisons only make sense when the absolute poverty threshold reflects (about) the same living standard in each country. Thus, an income equal to the poverty line in Italy should allow a household to purchase the same goods and services as the poverty line income in the United States. To obtain the absolute poverty lines for the European Members States we converted the official 1993 US thresholds using the 1993 Purchasing Power Parity (PPP) rates provided by the OECD. For the other years, we updated the national thresholds the using the Consumer Price Index (CPI) of each country. Below we shortly discuss the appropriateness of using PPP rates and we show the impact on poverty of using a different benchmark year.

The PPP indices have been developed to accurately compare macroeconomic indicators such as GDP while controlling for differences in price levels and exchange rates between countries. In practise, the PPP indices are used for various purposes, including international poverty comparisons (Smeeding, 2000 and Schreyer et al, 2002). ${ }^{36}$ The well known dollar-a-day poverty estimates of the World Bank are obtained using the same methodology. The main problem with the PPP rates is that they may not reflect the costs of buying those goods and services that are consumed at income levels around the poverty thresholds. One problem is that PPP rates are based on the prices of a goods basket that not only includes consumer products. A second issue is that high income people may consume other goods than those with a poverty line income. A third problem is that the relative quantities of goods consumed also vary by income; low income individuals or households spend more resources on basic costs of living (food, shelter)

\footnotetext{
${ }^{36}$ See Gottschalk et al (2000) and Castles (1996) for a discussion on the use of PPP rates and micro-based data comparisons of well-being.
} 
while expenditures on luxury goods, leisure activities are higher as income is higher. The International Comparison Program (ICP) of the World Bank is currently developing socalled Poverty-relevant PPPs (PPPP) which specifically take into account the costs and quantities of goods and services consumed by people living on the threshold level. ${ }^{37}$ Unfortunately, the PPPPs are not yet available, so we cannot explore differences in the poverty impact using both PPP rates. Given our current poverty estimates, we find it difficult to believe that in 1993 about $40 \%$ of the Portuguese had an income that was insufficient to cover the basic cost of living. We expect to find considerably lower absolute poverty rates for countries such as Ireland, Portugal, Greece, Italy and Spain if we could apply the newly developed PPPP rates.

Irrespective of the type of PPP rate used, poverty estimates are sensitive to the choice of the benchmark year. The PPP rate $(\mathrm{q})$ is defined as the number of currency units required to purchase the amount of goods and services equivalent to what can be bought with one unit of the currency of the base country. For the OECD PPP rates, the US is the base country. ${ }^{38}$ The poverty line $\mathrm{z}$ of country A at time $\mathrm{t}$ is obtained by multiplying the US thresholds with the PPP rate $(\mathrm{q})$ at time t:

$$
z_{A_{t}}=z_{U S t} * q_{t}
$$

Then, for any other year the poverty lines of country A are updated for the cost of living using consumer inflation rates $(\pi)$ :

$$
z_{A t+1}=z_{A t} *\left(1+\pi_{t}\right)
$$

Year to year PPP rates change when the relative cost of living changes between countries (i.e. the inflation rates differ) or when there are changes in the exchange rate. If the costs

\footnotetext{
37 These PPPPs will be made available in 2007 (ICP Newsletter, volume 3, number 3, October 2006, available on www.worldbank.org).

${ }^{38}$ If there is only one good in the basket, the PPP rate would be calculated as follows: $q_{t}=P_{A} * E / P_{U S}$, where $P_{A}$ is the price of this good in country A, $P_{U S}$ the price in the United States and E is the dollar exchange rate.
} 
of living in country A rise with respect to the cost of living in the United States, the PPP rate will increase (and the poverty line in country A as well). Even when inflation rates are constant, changes in the exchange rate influence the PPP rate and thereby the level of the poverty line.

\section{Figure 3: Impact of PPP benchmark year on absolute poverty in Greece}

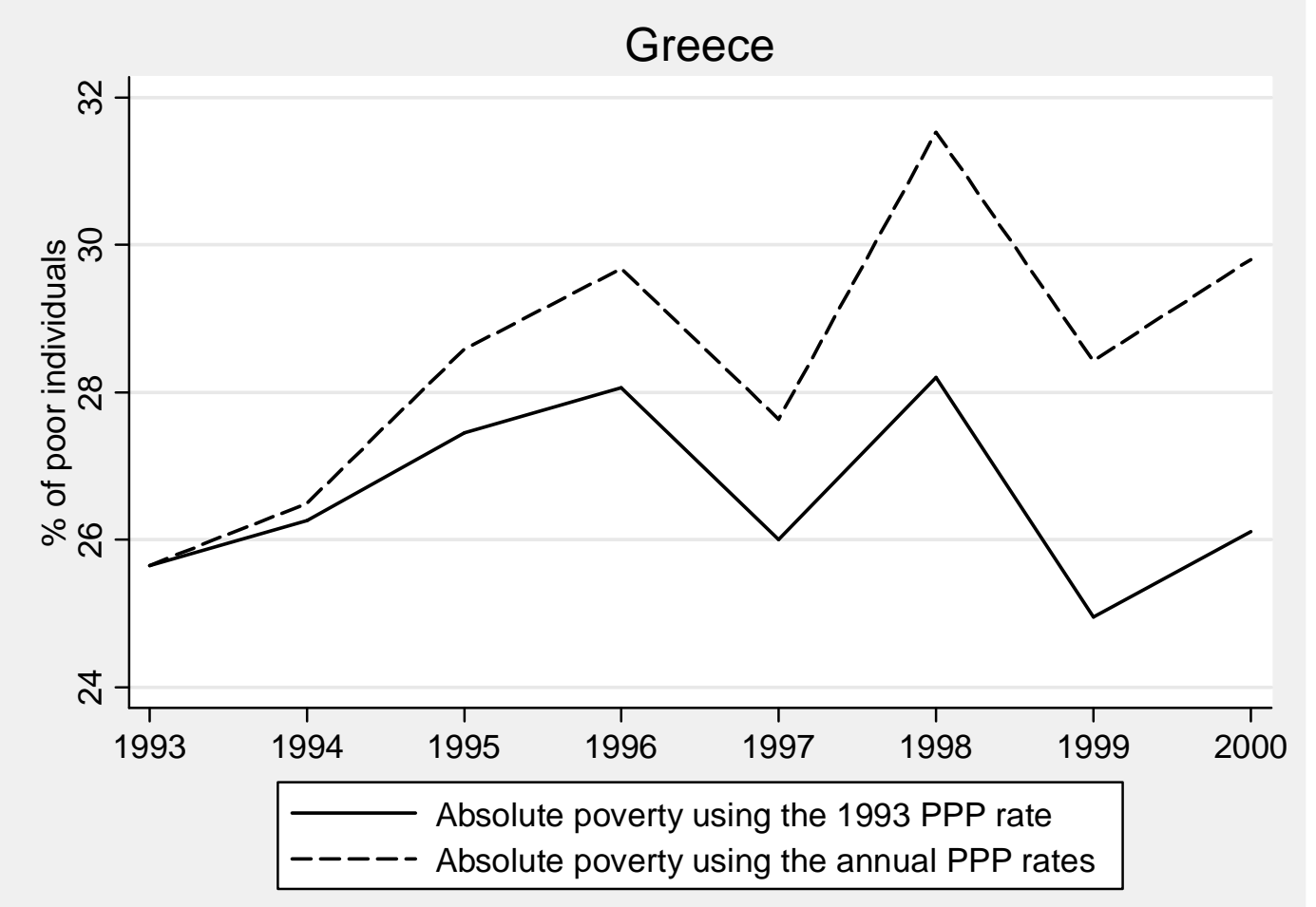

The choice for a particular PPP benchmark year thereby influences the poverty estimates. From 1993 to 2000, there were considerable changes in the PPP rates of countries such as Greece, Spain, Ireland, Italy and Portugal. Take for instance Greece, whose dollar PPP rate increased from 0.494 in 1993 to 0.685 in 2000 (and increase of $38 \%$ ). ${ }^{39}$ Figure 3 shows how absolute poverty in Greece changes by taking different benchmark years for PPP rates. The solid line shows the Orshansky poverty trends using the1993 PPP rates. The dashed line illustrates the Greek poverty rates if we would convert the US thresholds to Greek living standards every year. The impact of choosing a certain base year for PPP

\footnotetext{
${ }^{39}$ Using ECU/Euro as the national currency.
} 
conversion on poverty levels is reflected by the vertical distance between the lines. ${ }^{40}$ Thus, if we would have used the 2000 PPP rates, the absolute poverty rate in 2000 would be $30 \%$ as compared to $26 \%$. Choosing a different base year thus has a level effect on the absolute poverty rate but does not affect the poverty trend. ${ }^{41}$ The PPP changes for the other countries were considerably smaller and have therefore a much smaller impact on the level of poverty. Concluding, there is a certain arbitrariness involved in the choice for a benchmark year, although it makes sense not to choose for an 'unusual' year in terms of exchange rate or inflation levels. ${ }^{42}$

\subsection{Differences in poverty trends}

We identify two aspects that can influence observed differences in poverty trends between the official US and EU poverty rates. The first aspect relates to how the poverty line is updated from one year to the other in each official poverty method. The second aspect underlines the difference between absolute and relative approaches to poverty measurement and is explained by changes in the shape of the income distribution.

\subsubsection{Method for updating the poverty lines}

As shown in equation 8, the US thresholds are updated annually with the change in the consumer price index. This implies that changes in this absolute threshold are equal to the inflation rate.

\footnotetext{
40 The difference in poverty levels in Figure 3 may not only arise because of exchange rate trends. It may also be the result of inflation differences between consumer goods $(\pi)$ and the goods basket used for constructing PPP rates.

${ }^{41}$ Converting the thresholds every year using the yearly PPP rates is not a wise alternative, particularly if one is interested in studying changes in absolute poverty over time. This is because changes in the exchange rate could then affect the poverty trend.

${ }^{42}$ Most of the EU-15 countries were member of the European Monetary System (EMS) during the observed period and we thus involved in a joint effort to curb volatility of exchange rates. We preferred not to use the late nineties or 2000 because in these years the EMS was replaced by the European Monetary Union (EMU) which introduced a common currency for most of the Member States. Speculations on the success of these policy changes affected the exchange rates between those countries adopting the Euro and those not (United Kingdom, Sweden, Denmark) as well as those with the most important reserve currency in the world, the US Dollar. Furthermore, we chose 1993 simply because it was the first year in our data.
} 
The updating mechanism of the Laeken threshold is more implicit because the Laeken poverty line is determined by the yearly median income level. Thus, the Laeken threshold is updated every year with the change in median income.

$\Delta z_{r}=\Delta y_{m}$

In the countries we study here, low and stable inflation is an explicit monetary policy target and the monetary authorities are rather successful in achieving this target. As a result, price changes are less volatile than changes in economic growth (and income) over the business cycle. This implies that the updating mechanism used in the Laeken indicator functions as an in-built stabilizer on the poverty rates. In good times, the threshold is increased by the increase in median income but in bad times, the threshold could even decline (or increase by less than the inflation rate, a decline in real terms). The picture below illustrates with which growth rates the Orshansky and Laeken poverty lines are updated for the Netherlands. The growth rate of the Laeken threshold is clearly more volatile than that of the Orshansky threshold.

Figure 5 illustrates the effects of both updating methods on poverty trends for all countries. To isolate the effect of the updating mechanism we start from a single threshold in 1993 and update this threshold according to both methods. ${ }^{43}$ The updating methods influence the poverty trends in all countries; over time we can see a divergence in poverty trends with higher poverty rates when the change in median income as used as an updating mechanism. Divergence in trends is largest for countries that experienced high economic growth. This happens when median income levels also benefit from real economic growth; then the poverty line is not only adjusted for inflation but it is also adjusted for real income changes in society. Ireland is the extreme case in this respect, because the poverty trends are not just diverging but even move into the opposite direction. Also, the poverty trends with the Laeken updating mechanism appear more

\footnotetext{
${ }^{43}$ For Austria, Finland and Sweden we start with the year in which their first survey was held.
} 
stable than the trends using inflation updating (at least visually). This observation empirically supports the hypothesis that the Laeken updating mechanism has a stabilizing effect on the poverty rates. In addition, the distribution of benefits from economic growth also affects the poverty rates.

\section{Figure 4: Change in poverty lines due to different updating mechanisms}

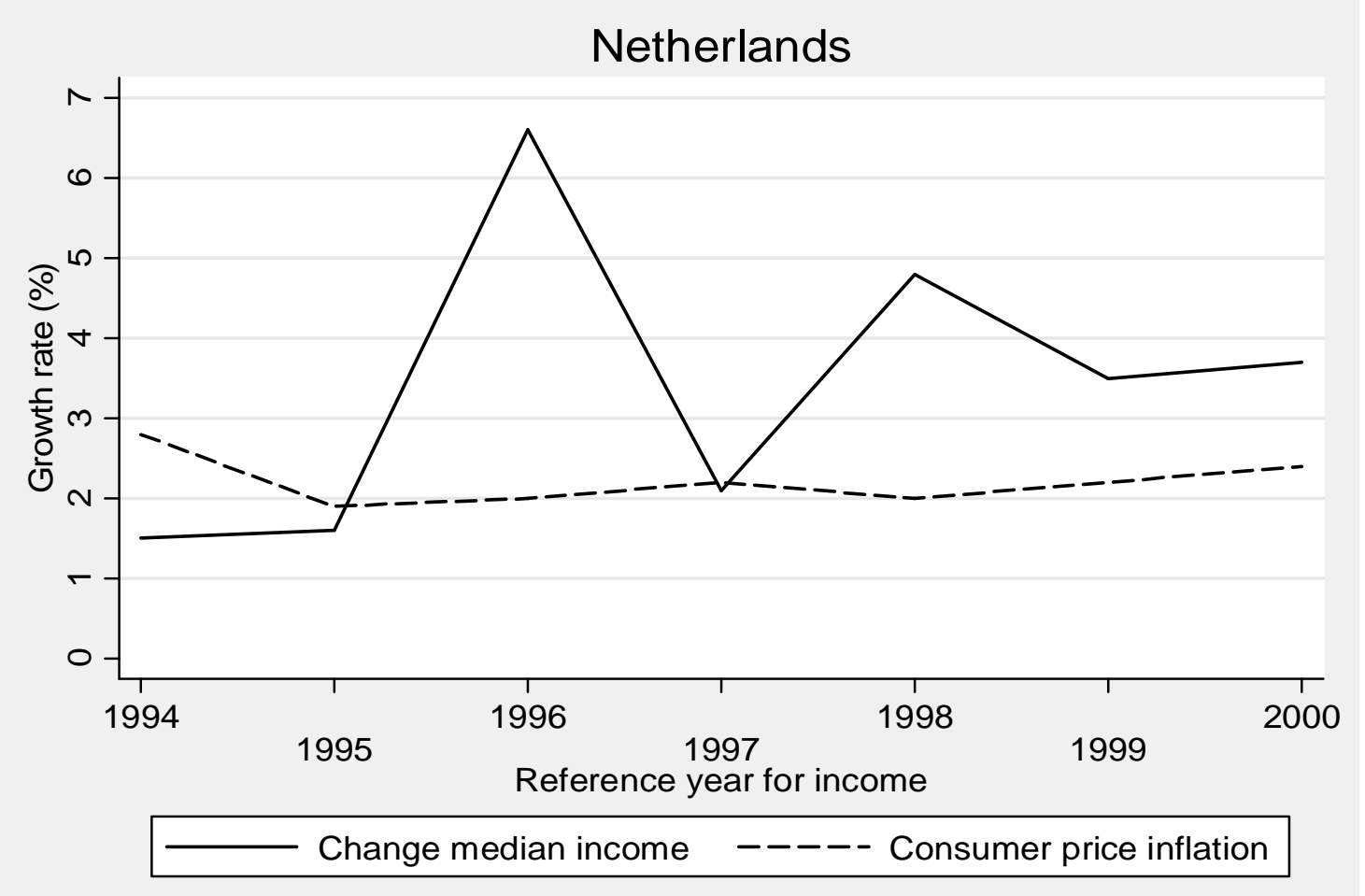

\subsubsection{Changes in inequality}

Differences in poverty trends can also be explained by a changing income distribution (i.e. changes in inequality). The intuition is as follows. Relative poverty rates do not change when all incomes grow at the same rate. This is because the relative poverty line and everyone's income is updated with the same growth rate. If the income of the poorer percentiles of the population grows less than that of the median; relative poverty rates are likely to increase. We use growth incidence curves (GIC) to illustrate this argument more specifically. A GIC shows the growth of income at each percentile of the distribution. Using the cumulative income distribution (CDF) specified in equation 1 and following 
Ravallion and Chen (2003, p. 94), inverting the CDF at the $\mathrm{p}^{\text {th }}$ quantile gives the income of that quantile:

$$
y_{t}(p)=F_{t}^{-1}(p)=L_{t}^{\prime}(p) \mu_{t} \quad\left(y_{t}^{\prime}(p)>0\right)
$$

where $L_{t}(p)$ is the Lorenz curve (with slope $L_{t}^{\prime}(p) \mu_{t}$ and the mean $\mu_{t}$ ). The Lorenz curve shows the income share of total income owned by the bottom $x$ percent of people (when incomes are ranked from low to high). The growth rate in income of the $\mathrm{p}^{\text {th }}$ quantile is:

$$
g_{t}(p)=\left[y_{t}(p) / y_{t-1}(p)\right]-1
$$

Letting $\mathrm{p}$ vary from zero to one, $g_{t}(p)$ indicates the growth incidence curve. It follows from equation 11 that:

$$
g_{t}(p)=\frac{L_{t}^{\prime}(p)}{L_{t-1}^{\prime}(p)}\left(\gamma_{t}+1\right)-1
$$

where $\gamma_{t}=\left(\mu_{t} / \mu_{t-1}\right)-1$ is the growth rate of average income $(\mu)$. Thus, if there are no changes in inequality (i.e. the Lorenz curve stays the same), the GIC will be a flat line at the average income growth rate. If $g_{t}(p)$ is a decreasing function for all $\mathrm{p}$, then inequality is reduced over time (and vice versa).

It is important to realize that a GIC explains the growth patterns of the aggregate distribution. It does not necessarily reflect the experienced income growth of the individuals or households making up that distribution because they can also move within the income distribution (individuals lose a job, get promotion, retire and thereby change their position in the income ranking). Even though being poor (or not) is a status which applies to individuals and not to $\mathrm{p}^{\text {th }}$ quantiles, GIC's are also a useful tool to explain poverty trends. This is because trends in aggregate poverty measures are (for a large part) explained by changes in the income distribution (i.e. inequality). 
Figure 5: The impact of updating mechanisms on poverty incidence

\section{Impact of updating poverty line on poverty}
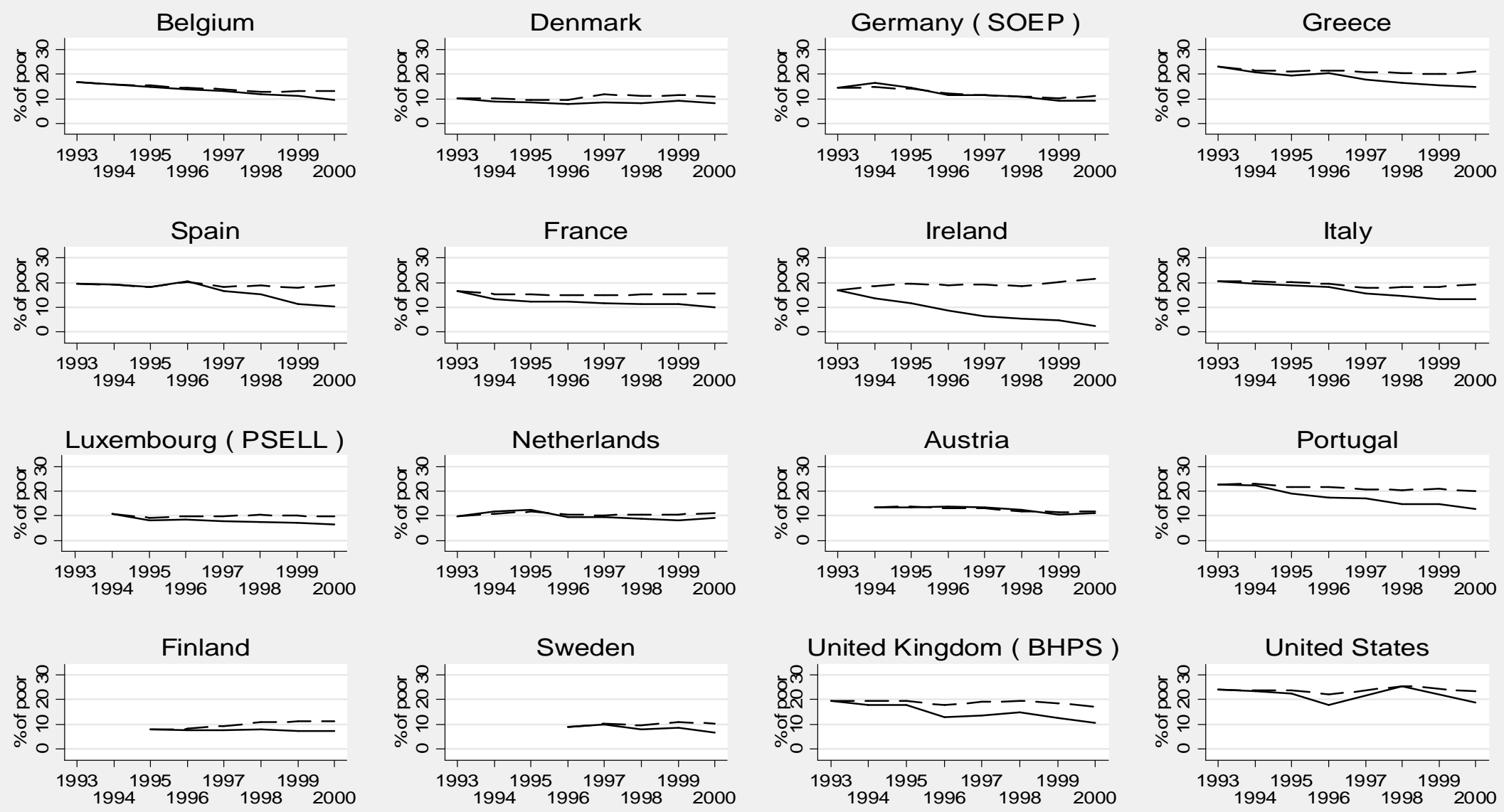

Update change median income

Update CPI 
Let us first start with absolute poverty and assume that the absolute poverty line is only adjusted for inflation. For simplicity, we imagine a world with no distributional mobility (individuals do not switch ranks in the income distribution) or, equivalently, there is mobility, but each move in ranks is compensated by an exact countervailing move. In such a situation, changes in absolute poverty can entirely be explained by the real income changes of the percentiles around the poverty line. Everything else equal, absolute poverty increases (decreases) when the real income growth rates of those percentiles just above (under) the poverty line are negative (positive).

For relative poverty rates the argument changes a bit because the poverty line is determined endogenously by the income distribution. In the case of the Laeken approach, relative poverty rates can be explained by a combination of the real income changes of the percentiles around the poverty line and those of the median $\left(50^{\text {th }}\right.$ percentile $)$. Relative poverty increases (decreases) when the real growth rate at the median is higher (lower) than the growth rates of the percentiles above (below) the poverty line.

We have graphed the GICs for each country using the 1993 and 2000 income distributions (Figure 6). The curves are expressed in average annual real growth rates. For most countries, the growth rates are averaged over 8 years. The curve shows the GIC and the horizontal line reflects the average annual growth rate of median income. To enhance comparability between countries, we excluded the lowest and highest 5 percentiles because they had a too large effect on the scaling of the vertical axis. For the same purpose, we allowed the vertical axis to differ by country. If all incomes grow at the same rate, the GIC is flat and there are no changes in inequality. Also note that the GICs are drawn comparing the income distributions of 1993 and 2000 which implies that they do not necessarily reflect inequality changes occurring between intermediate years.

A first observation is that the growth patterns of the countries are very different in terms of growth levels as well as in the way income growth is distributed over the population. In many countries, the lower end of the income distribution benefited most from economic growth, but this is not the case in Denmark, Finland, Sweden and Ireland where 
the opposite pattern occurs. To see how poverty trends can be explained by these growth patterns, we need focus on those income percentiles around the poverty rates and the median percentile (the latter only for Laeken poverty). The case of Ireland clearly illustrates these effects. In the period from 1993 to 2000, Ireland experienced rapid economic growth. Every percentile benefited from this growth; percentile income growth rates are mostly at or above $4 \%$ per annum. As the Orshansky threshold did not change in real terms, absolute poverty rates in Ireland should have decreased. Indeed, in 1993, 30\% of the Irish had an income below the Orshansky threshold and in 2000 poverty rates were below $11 \%$ (table A4 in the appendix summarizes poverty rates by country and year). However, the GIC from Ireland shows that the middle income groups benefited much more than other groups; median income grew by more than $6 \%$. The relative poverty threshold thus also increased by more than $6 \%$ per annum while the growth rates around the poverty line percentiles (16-21) were about 5\%. As a result, relative poverty increased in Ireland therefore (from $17 \%$ in 1993 to $21 \%$ in 2000).

For most of the countries, the GIC patterns explain the poverty trends rather well. Although at low poverty rates and/or low growth rates it is more difficult to graphically see the effects. Note that there is there are contrasting experiences among the faster growing countries (Greece, Spain, Portugal, and Ireland)). In Greece, Spain and Portugal the lower 20 percentiles had higher growth rates than the median income percentile while Ireland experienced the opposite.

\subsection{Equivalence scales and the impact on absolute and relative poverty rates}

Equivalence scales adjust for the economies of scale that larger households have as compared to a single person household. They also adjust for differences in cost of living for different age and/or gender groups. A natural benchmark for determining equivalence scales would be the differences in costs for households with a poverty line income in a given country, but this is not always common practice. Cross national poverty comparisons typically apply the same equivalence scales to every country even though it is likely that the costs differ between countries. The Laeken and Orshanky methods also 
Figure 6: Growth incidence curves (expressed in real annual growth rates, based on using survey data from 1993 and 2000)

\section{Growth Incidence Curves (period 1993-2000)}
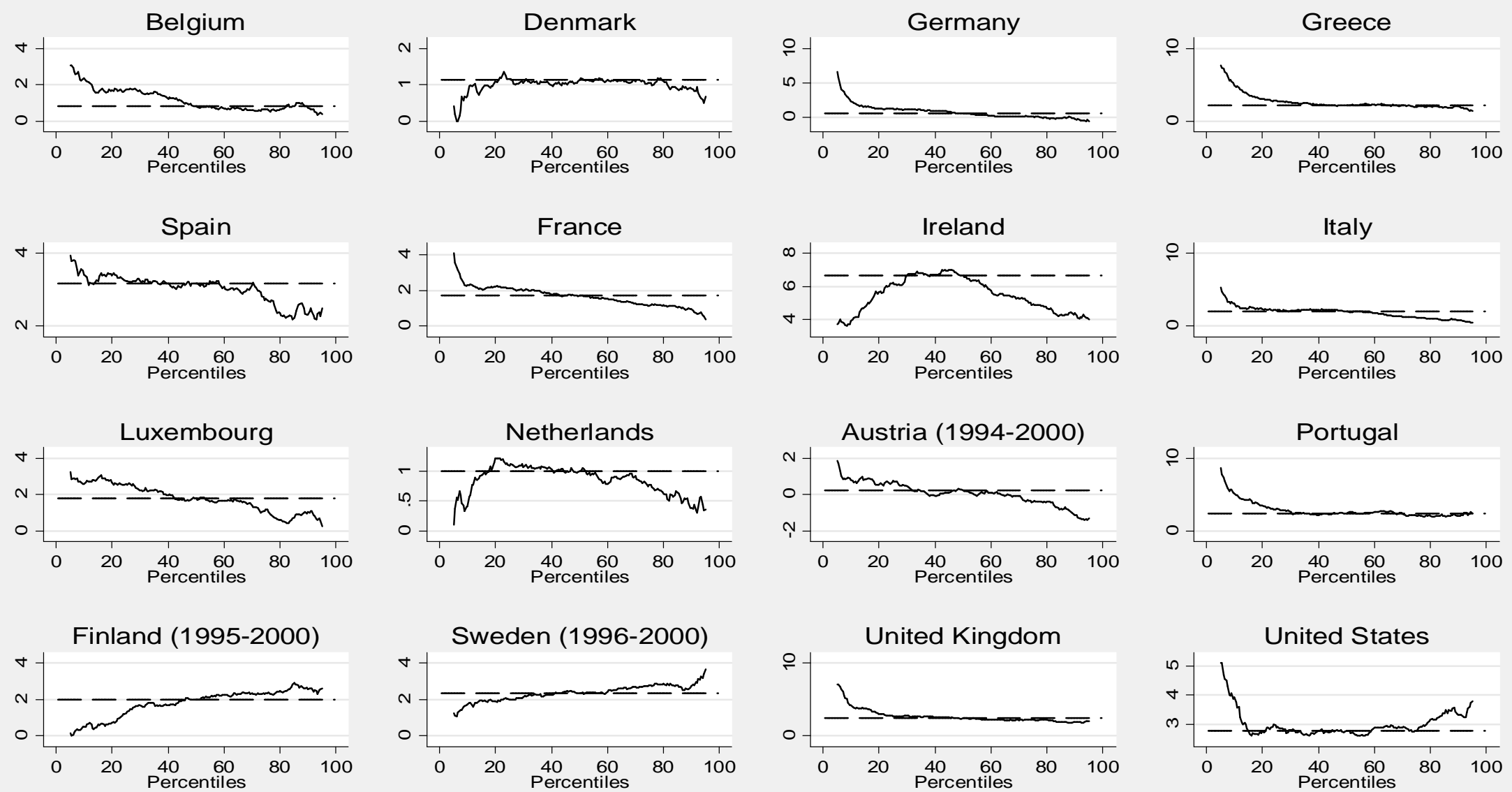

Annual growth rate income Annual growth rate median income 
use different equivalence scales. In this section we explore how those weighting schemes differ and how they impact the Laeken and Orshansky poverty estimates.

The modified OECD equivalence scales used in the Laeken indicator assign a weight to each household member. The first adult receives a weight of 1 and subsequent adults get a weight of 0.5 . Children under age 14 , each obtain a weight of 0.3 . A household consisting of two parents and two children thus receives a weight of 2.1. Subsequently, the household's income is then divided by 2.1 to obtain the adult equivalent income. All individuals in the household are poor when the adult equivalent income lies below the adult equivalent poverty line. We derived the Orshansky equivalence scales from the 48 poverty lines. Which poverty line is applied to the household depends on the number and age of the household members. Household members under the age of 18 are counted as children. For the single and two person households a further distinction is made with respect to the age of the head of the household. If the head is older than 65 , the household has a lower threshold. We calculated the implied Orshansky equivalence scales by taking the single adult household poverty line as a benchmark. ${ }^{44}$

Table 2: Total household weight using various equivalence weighing schemes

\begin{tabular}{|c|c|c|c|c|}
\hline Household types & Individual & $\begin{array}{c}\text { Modified OECD } \\
\text { scales (Laeken) }\end{array}$ & $\begin{array}{c}\text { Implied } \\
\text { Orshansky scales }\end{array}$ & Household \\
\hline Single adult & 1 & 1 & 1 & 1 \\
\hline Single elderly & 1 & 1 & 0.92 & 1 \\
\hline Couple adult & 2 & 1.5 & 1.29 & 1 \\
\hline Couple elderly & 2 & 1.5 & 1.16 & 1 \\
\hline $\begin{array}{l}\text { Single parent, one } \\
\text { child }\end{array}$ & 2 & 1.3 & 1.32 & 1 \\
\hline $\begin{array}{l}\text { Single parent, two } \\
\text { children }\end{array}$ & 3 & 1.6 & 1.55 & 1 \\
\hline Parents one child & 3 & 1.8 & 1.55 & 1 \\
\hline $\begin{array}{l}\text { Parents two } \\
\text { children }\end{array}$ & 4 & 2.1 & 1.95 & 1 \\
\hline $\begin{array}{l}\text { Parents three } \\
\text { children }\end{array}$ & 5 & 2.4 & 2.29 & 1 \\
\hline
\end{tabular}

\footnotetext{
${ }^{44}$ For example, the poverty line of a single adult is $\$ 1,000$ and $\$ 2,000$ for a household consisting of two adults and two children. The (implied) equivalence weight of the latter household is $\$ 2,000 / \$ 1,000=2$.
} 
Table 2 compares the total household weights for a number of household types using the OECD and Orshansky weighting schemes. We have also included two extreme scales; the individual scheme which gives a weight of 1 to every individual and the household scheme which gives a weight of 1 to each household, irrespective of its composition. Single elderly households get a weight of 1 for all schemes except the Orshansky scheme, which attributes a weight of 0.92 . Thus, single elderly 'need' only $92 \%$ of the income required for a single adult, or alternatively, the poverty line of a single elderly is $92 \%$ of the single adult's poverty line. Compared to the household and individual weighting schemes the OECD and Orshansky scales are rather similar. For most household types the Orshansky scales have a lower value then the OECD scales, this implies that the Orshansky scales assume that these household types require lower cost to reach the same level of economic well being. ${ }^{45}$ In contrast to the OECD scales, where additional adults have a higher weight than children, the Orshansky scales often give a slightly higher weight to children than to additional adults. For instance, single parents with one child receive an Orshansky weight of 1.32 and an OECD weight of 1.3. The adult couple household also consists of two persons but here the OECD weight is 1.5 while the Orshansky weight is 1.29 .

Even though the differences between the Laeken and Orshansky equivalence scales are not so large, they can have a considerable impact on overall poverty rates as well as on poverty rates for certain groups in society. Moreover, equivalence scales affect the Laeken and Orshansky poverty rates differently. To see this, the adult equivalent income $\left(y_{e}\right)$ of household $\mathrm{i}$ is obtained by dividing household income $y_{i}$ by its equivalence scale $E_{i}$. Then, for most households the OECD equivalence scale is larger than the Orshansky equivalence scale, resulting in a lower equivalent adult income. Using the same absolute (equivalent adult) poverty line, it can easily be seen that absolute poverty rates using the Orshansky weights are higher than with the OECD scales.

\footnotetext{
${ }^{45}$ For some more atypical households, notably households with many children and relatively few adults, the Orshansky scales indicate a higher cost than the modified OECD scales.
} 
If, for most households, $E_{O E C D}>E_{\text {orshansky }}$, then $y_{O E C D}<y_{\text {orshansky }}$ and for a given $z_{a}$ then $H_{O E C D}>H_{\text {orshansky }}$.

Figure 7: Difference between Laeken and Orshansky poverty rates due to different equivalence schemes (in percentage points)

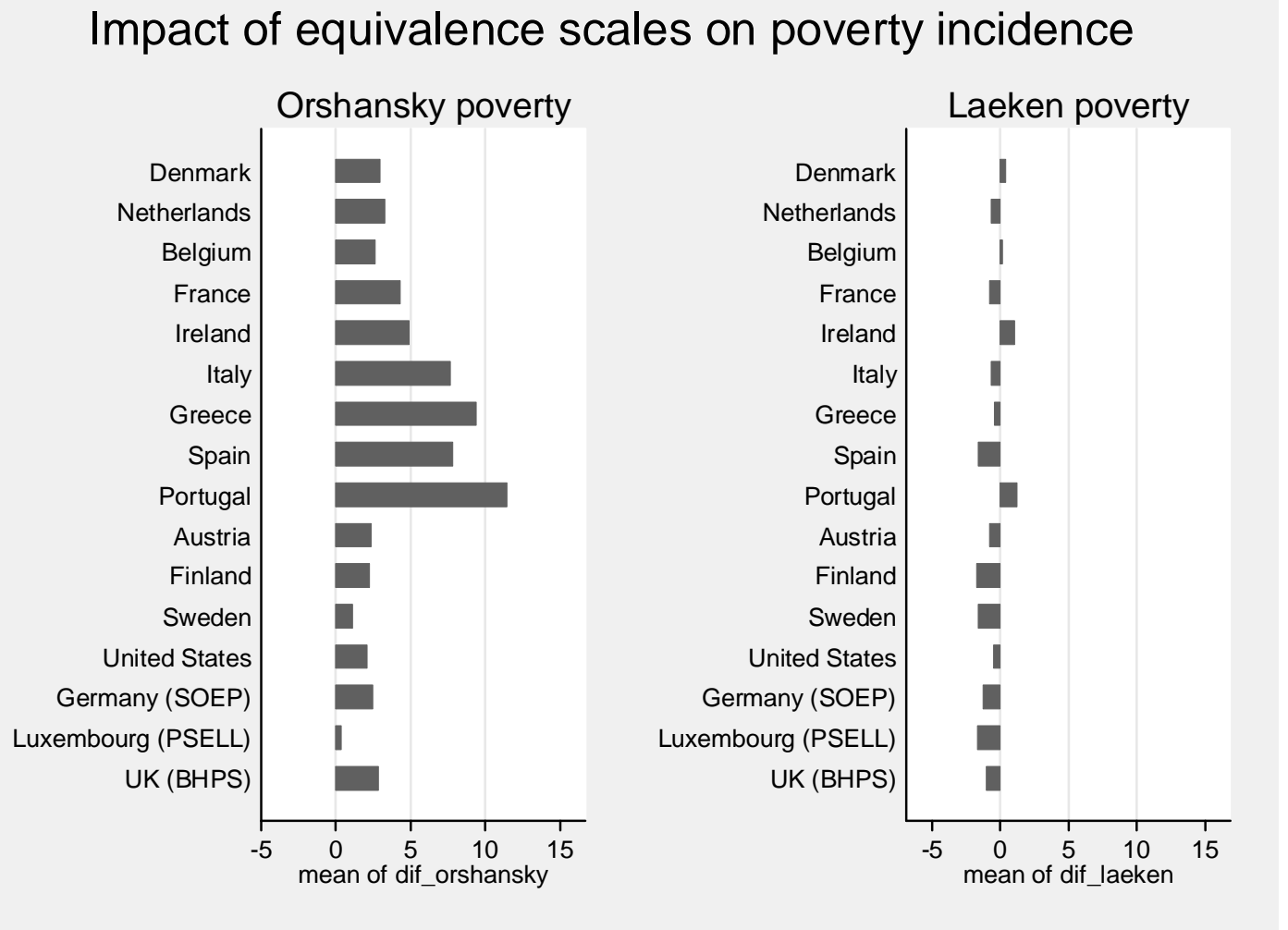

For the Laeken poverty rates, it is with the above information, not clear how the equivalence schemes affect the relative poverty rates. This is because the equivalence scales not only weigh income differently, but for the relative poverty line they also determine the locus of the poverty line. The net effect on poverty depends on the demographic composition of the population (the relative size of the three generations and how they are spread over household types) and the income of these households. If, for most households, $E_{O E C D}>E_{\text {orshansky }}$, then $y_{O E C D}<y_{\text {orshansky }}$ and $z_{r(O E C D)}<z_{r(\text { orshansky })}$ (because $\left.y_{m(O E C D)}<y_{m(\text { orshansky) }}\right)$. As lower equivalent adult income tends to increase poverty rates while a lower poverty line decreases poverty rates, the net impact on relative poverty is not clear. 
We have calculated the 2000 Orskansky poverty rates using the original equivalence weights and the modified OECD equivalence scales and we also did this for the Laeken poverty rates. Figure 7 shows the impact of both weighting schemes on the overall poverty rates by illustrating the percentage point difference. As expected the Orshansky poverty rates are higher when using the modified OECD scales. For example, in Ireland Orshanky poverty rates are 5 percentage points higher if we would apply OECD equivalence scales. The differences in Laeken poverty rates are much smaller and are positive in some countries while negative in others; overall relative poverty rates are less sensitive to the use of different equivalence scales.

Figure 8: Difference between Laeken and Orshansky poverty rates due to different equivalence schemes (by household type, in percentage points)

\section{Impact of equivalence scales on Orshansky and Laeken poverty}
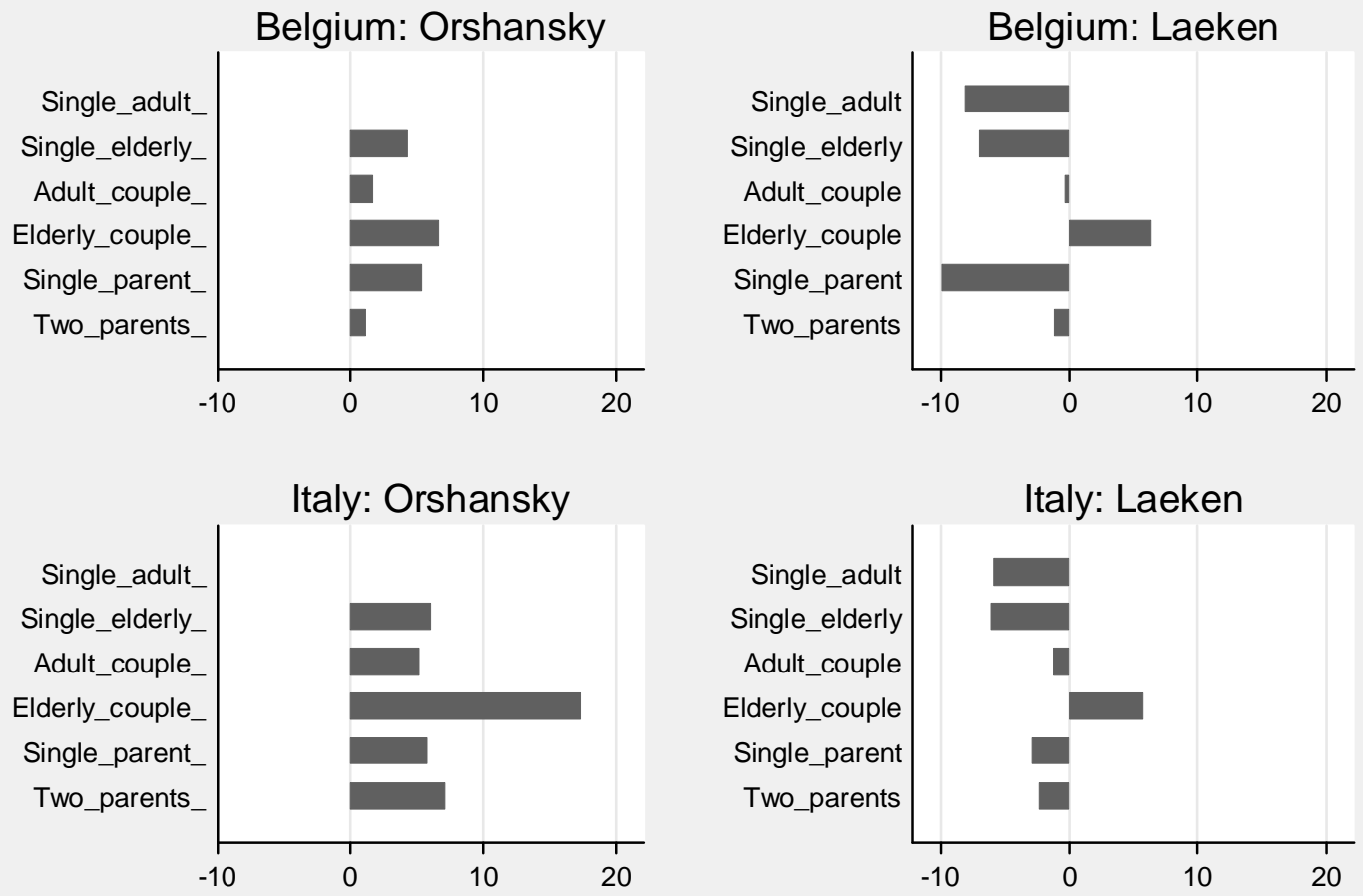

We also illustrate the impact of the Orshansky and OECD weighting schemes for six household types: single adult, single elderly, adult couple, elderly couple, single adult 
with child(ren) and two adults with child(ren). Because the number of observations for single parents is very low in some countries, the results for this group should be interpreted with caution. The poverty differences for the Orshansky poverty rates are larger for households with children and/or larger households (Figure 8). Austria is the only country where single parents (of one or more children) have a lower poverty rate using the Orshansky scales. Looking at Figure 8 we find that the small Laeken poverty differences mask considerable changes in relative poverty risk for different household types. The poverty differences are negative for some household types and positive for other types but the direction of the effect is common for all countries. Poverty rates among elderly couples are larger in all countries when using OECD equivalence scales while poverty rates among single adults, single elderly and single parents are smaller. The differences for adult couples and parents with children are only small.

Concluding, the impact of different equivalence scales on overall poverty rates is larger on absolute poverty rates. Nevertheless, equivalence scales affect the relative poverty risks of groups in society; using a different equivalence scale alters the poverty risk of one group relative to the other. Knowing the equivalence weighting schemes, it is easy to assert the direction of change in poverty risk for a certain group for absolute poverty. Using a relative approach to poverty, the direction of change in poverty risk for specific groups depends not only on the equivalence weights but also on the composition of the population.

\section{Conclusion}

In this paper we applied the official poverty measurement methods of the United States and the European Union to both regions in order to explain underlying reasons for differences in relative and absolute poverty. We used within and between country perspectives to explain differences in poverty levels and trends and showed the impact of each of these aspects on poverty levels and poverty trends while keeping other explanatory factors constant. 
Differences in inequality and changes in inequality over time affect absolute and relative poverty levels and poverty trends. Firstly, countries with higher income dispersion below the poverty line have higher relative poverty rates. Countries with lower income inequality such as Sweden or the Netherlands thus have lower relative poverty rates than the US and UK. Note however, that this relation only holds for a rather narrow concept of inequality (only inequality at and below the median person affects the poverty) and that relative poverty results may conflict with other indicators of inequality. Moreover, because absolute thresholds do not take distributional characteristics into account, countries with higher income dispersion are more likely to have larger differences between absolute and relative poverty rates. This is especially likely in the case when the absolute threshold is based on some assessment of the minimum amount of resources needed to cover the basic cost of living. Secondly, we showed that changes in poverty can explained by aggregate real income changes of the percentiles around the poverty line (absolute poverty) and income changes at mean or median income levels (absolute and relative poverty). The opposing poverty trends in Ireland in the nineties can for a large part be attributed to the overall improvement in living standards combined with an increasing income inequality; everyone benefited (decreasing absolute poverty), but those people at the median benefited more than those below (increasing relative poverty).

We also showed that each poverty method updates the monetary value of the poverty line from one year to the other in a different way and this can affect poverty trends. As price changes are less volatile than (real) changes in economic growth and income, the growth rates of the Orshansky poverty line are more stable than those of the Laeken poverty line. On the other hand, the updating mechanism used in the Laeken indicator functions as an in-built stabilizer on the poverty rates. In good times the threshold is increased by the increase in median income, but in bad times the threshold could even decline.

Choosing a benchmark year for the conversion of absolute poverty lines to national cost of living using Purchasing Power Parity rates influences absolute poverty levels. This particularly affects countries such as Greece, Spain, Ireland, Italy and Portugal because they have experienced considerable changes in cost of living relative to those in the 
United States during the 1990s. Clearly, such differences can affect the ranking of countries in international poverty comparisons. This also holds for the new Poverty PPP rates that will be introduced by the World Bank. At the same time, these results are also a reminder that regional price differences within a country affect the results of a poverty analysis; something that we did not adjust for in this paper.

Finally, we analyzed how equivalence scales affect absolute and relative poverty rates. We found that the impact of different equivalence scales on overall poverty rates is larger for absolute poverty rates. The impact on overall relative poverty rates is much smaller because the weighting schemes also affect the position of the relative poverty line. Nevertheless, in both poverty approaches using different equivalence scales alters the poverty risk of one group relative to the other.

The results of our analysis suggest that it makes sense to use both absolute and relative poverty indicators. Absolute poverty analyses provide insights into the parts of the population that do not attain the minimal living standard. Relative poverty analyses inform about the group of people whose living standard is low compared to that of the society they live in. Relative and absolute approaches thus each portray different poverty dimensions; monitoring one dimension does not provide information on developments in the other dimension. Obviously, in certain cases one poverty indicator may be more relevant than the other; take for instance the evaluation of last resort social safety nets. In the countries we studied, social assistance programs are typically directed to assist those groups that are not able to attain certain minimum standard of living. Eligibility for these programs is often established through means or income test in combination with other criteria. An absolute poverty approach helps to identify those groups that would need (further) attention. Nevertheless, tax regimes, social insurance, social assistance programs and the provision of public goods all affect the income distribution of a society and thus influence the number and characteristics of the poor (absolute and relative), underlining the relevance of using both poverty approaches. Moreover, societal preferences on redistribution are typically not positive (Is inequality fair or not? Do we redistribute or not?) but subjective (What level of inequality is (not) acceptable? How much do we want 
to redistribute?). Ignoring one dimension might thus lead to developments in society that at some point may conflict with societies' preferences and delayed actions.

Even though most countries in the developed and developing world report (semi) official poverty statistics on a regular basis, only few countries (among which Ireland) actually report both absolute and relative poverty statistics. In fact, it is not easy to find comparable absolute and relative poverty data (the poverty research based on the Luxembourg Income Study (LIS) data being a noteworthy exception). Unfortunately, it seems that a 'battle of the rates' takes place only when deciding about which official poverty indicator to choose (EU) or to discuss the deficiencies of the current indicator (US and EU). The inequality tolerance argument put forward in the previous paragraph suggests that even in the United States a relative poverty approach can play an important role in public debate. And why does the EU only use a relative approach while differences in living standards between Member States are large and have further increased with current expansions of the European Union? How should we interpret the fact that the Czech Republic has the lowest Laeken poverty rate within the EU? We argue that the Laeken indicators should be complemented with an absolute poverty line that reflects the cost of achieving a minimum living standard in each member state (including costs such as food, rent, clothing, health and education). The new Member States are still in the process of restructuring their economies and it is expected that there will be strong economic growth; all reasons for expecting divergence between absolute and relative poverty levels and trends in these countries.

\section{Literature}

Alesina, A. and E.L. Glaeser (2004), Fighting Poverty in the US and Europe; a World of Difference, Oxford University Press, Oxford.

Atkinson, T., B. Cantillon, E. Marlier and B. Nolan (2002), Social Indicators; The EU and Social Inclusion, Oxford University Press, Oxford. 
Butrica, B.A. and R.V. Burkhauser (1997), Estimating Federal Income Tax Burdens for Panel Study of Income Dynamics (PSID) Using the National Bureau of Economic Research TAXSIM Model, Maxwell Center for Demography and Economics of Aging, Syracuse University, New York, 13244-1020.

Burkhauser, R.V., B.A. Butrica, M.C. Daly and D.R. Lillard (December 2000), The Cross-National Equivalent File: A Product of Cross-National Research, Soziale Sicherung in Einer Dynamischen Gesellschaft (Social Insurance in a Dynamic Society), Irene Becker, Notburga Ott, and Gabriele Rolf (Eds.), Festschrift fuer Richard Hauser zum 65. Geburtstag (Papers in Honour of the $65^{\text {th }}$ Birthday of Richard Hauser).

Castles, I. (1996), Review of the OECD-Eurostat PPP Program, STD/PPP(97)5, Economic Studies Branch, Paris, France, OECD.

Citro, C. and R. Michael (1995), Measuring Poverty: a New Approach, Panel on Poverty and Family Assistance, Committee on National Statistics, National Research Council. Washington, D.C.: National Academy Press.

Duclos (2006) J. and A. Araar, Poverty and Equity; Measurement, Policy and Estimation with DAD, Springer, New York.

Euro Panel Users Network (July 2004), ECHP user Guide, Institute for Social and Economic Research, University of Essex, available online on http://epunet.essex.ac. uk/ECHP_USER_GUIDE_06-07-2004b.pdf (retrieved August 2005).

Eurostat (2003), Construction of weights in the ECHP, DOC. PAN 165/2003-06, available online on http://forum.europa.eu.int/Public/irc/dsis/echpanel/library?l=/user_db $\& v m=$ detailed\&sb=Title (retrieved August 2005). 
Eurostat (2003), ECHP UBD Description of Variables, DOC. PAN 166/2003-12, available online on http://forum.europa.eu.int/Public/irc/dsis/echpanel/library?1 $=/$ user_db\&v m=detailed\&sb=Title (retrieved August 2005).

Eurostat (2002), Imputation of Income in the ECHP, DOC. PAN 164/2002-12, available online on http://forum.europa.eu.int/Public/irc/dsis/echpanel/library?l=/user_db\&v $\underline{m}=$ detailed $\& s b=$ Title (retrieved August 2005).

Eurostat (2003), 'Laeken' Indicators; Detailed Calculation Methodology, Working Group Statistics on Income, Poverty and Social Exclusion, DOC. E2/ISPE/2003, available online on http://forum.europa.eu.int/Members/irc/dsis/soipase/home (retrieved August 2005).

Feenberg, D. and E. Coutts (1993), An Introduction to the TAXSIM Model, Journal of Policy Analysis and Management, 12(1), pp. 189-194.

Fischer, G.M. (1992), The Development of the Orshansky Poverty Thresholds and Their Subsequent History as the Official U.S. Poverty Measure, partially revised 1997, available online on http://www.census.gov/hhes/www/povmeas/papers/orshansky.html (retrieved August 2005).

Förster, M. and M.M. d'Ercole (2005), Selection of Figures: Income Distribution and Poverty in OECD Countries in the Second Half of the 1990s, OECD Social, Employment and Migration, Working Paper, 22, available online on www.oecd.org/els/workingpapers (retrieved August 2005).

Foster, J., Greer, J. and E. Thorbecke (1984), A Class of Decomposable Poverty Measures, Econometrica, 52, pp.761-65.

Gottschalk, P. and T. Smeeding (2000), Cross-National Comparisons of Earnings and Income Inequality, Journal of Economic Literature, 35(2), pp.633-687. 
Gouskova, E. and R. Schoeni (2002), Comparing Estimates of Family Income in the Panel Study of Income Dynamics and the March Current Population Survey, 1968-1999, Institute for Social Research, University of Michigan.

Hulme, D., and A. Shepherd (2003), Conceptualizing Chronic Poverty, World Development, 31(1), pp. 403-423.

O’Boyle, E.J. (1999), Toward an Improved Definition of Poverty, Review of Social Economy, 57(3).

Oxley H., T.T. Dang, M. Förster, M. Pellizari (2000), Income Inequalities and Poverty among Children and Households with Children in selected OECD Countries: Trends and Determinants, in K. Vleminckx and T.M. Smeeding (eds), Child Well-Being, Child Poverty and Child Policy in Modern Nations, The Policy Press, Bristol.

Ravallion, M. and S. Chen (2003), Measuring Pro-poor Growth, Economic Letters 78, pp. 93-99.

Ravallion, M. (1994), Poverty Comparisons, Fundamentals of Pure and Applied Economics, 56, Harwood Academic Publishers GmbH.

Rendtel, U., L. Nordberg, M. Jäntti, J. Hanisch and E. Basic (January 2004), Report on Quality of Income Data, the Change from Input Harmonization to Ex-post Harmonization in the National Samples of the European Community Household Panel - Implications on Data Quality (CHINTEX), Chintex working paper, 21.

Schreyer, P. and F. Koechlin (2002), Purchasing Power Parities - Measurement Issues, Statistics Brief, 3, OECD, Paris. 
Smeeding, T.M. (2005), Poor People in Rich Nations: The United States in a Comparative Perspective, Luxembourg Income Studies Working Paper, 419.

Smeeding, T.M., L. Rainwater and G. Burtless (2000), United States Poverty in a CrossNational Context, Luxembourg Income Studies Working Paper, 244.

Smeeding, T.M. and K. Ross (1997), Financial Poverty in Developed Countries: The Evidence from LIS, Luxembourg Income Studies Working Paper, 155.

Yong-Seong, K. and F. Stafford (2000), The Quality of PSID Income Data in the 1990's and Beyond, available on http://psidonline.isr.umich.edu/Guide/Quality/q_inc_data.html (retrieved March 2006). 


\section{Appendix}

Table A1: Number of observations by country and survey year

\begin{tabular}{|c|c|c|c|c|c|c|c|c|c|c|c|c|c|c|c|c|}
\hline \multirow[t]{2}{*}{ Survey year } & \multicolumn{2}{|c|}{1994} & \multicolumn{2}{|c|}{1995} & \multicolumn{2}{|c|}{1996} & \multicolumn{2}{|c|}{1997} & \multicolumn{2}{|c|}{1998} & \multicolumn{2}{|c|}{1999} & \multicolumn{2}{|c|}{2000} & \multicolumn{2}{|c|}{2001} \\
\hline & \# hh & $\#$ ind & hh & $\#$ ind & \# hh & $\#$ ind & \# hh & $\#$ ind & $\#$ hh & $\#$ ind & hh & ad & \# hh & \# ind & hh & $\# \mathrm{i}$ \\
\hline 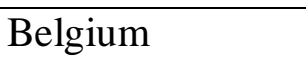 & 3 & & & & & & & & & & & & & & 322 & \\
\hline Den & 78 & 37 & 217 & 192 & 50 & & & & & & 76 & & 72 & & 279 & 30 \\
\hline G & & & 93 & & 6,207 & & & & 91 & & 82 & & 19 & & 74 & 33 \\
\hline & & & & & & & & & & & & & & & & \\
\hline & & 37 & 448 & 20 & 28 & & 14 & & 38 & & 5,291 & & 46 & & 4,948 & 70 \\
\hline & & & 9 & $1^{\prime}$ & & & & & 49 & & 93 & & 31 & & 47 & \\
\hline & & & & & & & & & & & & & & & 57 & \\
\hline & & & 04 & & 7,026 & & & & & & & & & & 25 & \\
\hline & & & 76 & & & & & & 2,521 & & 2,550 & & 2,373 & & 2,428 & 6,306 \\
\hline & 39 & 95 & 35 & 12 & & & & & 4,922 & 12 & 81 & & 74 & & 324 & 12,027 \\
\hline & $\mathrm{n}$ & & & & & & & & & & & & & & 35 & \\
\hline & 4,787 & 14,500 & 4,869 & 14,717 & & & & & & 13 & 4,645 & & 4,606 & & 4,588 & 13,237 \\
\hline & na & na & na & na & 4,138 & 12 & 03 & & 17 & 0 & 18 & & 01 & 49 & 06 & 180 \\
\hline & na & na & na & $\mathrm{n}$ & 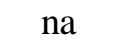 & & 5,286 & 12 , & 5,208 & 12,451 & 5,165 & 12,283 & 5,116 & 12,104 & 5,085 & 12,045 \\
\hline & & & مه & & & & & & 4,928 & 12,236 & 4 & & 4,793 & 11,904 & 4,702 & 11,710 \\
\hline 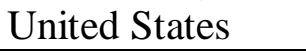 & 675 & 24 & 325 & 20,109 & 10 & 21 & 39 & 93 & na & na & 5,874 & 16 & 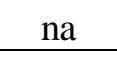 & . & 5,908 & 16 \\
\hline
\end{tabular}


Table A2: Per capita income by country and survey year (in Euro) ${ }^{12}$

\begin{tabular}{lcccccccc}
\hline \multicolumn{1}{c}{ Survey year } & $\mathbf{1 9 9 4}$ & $\mathbf{1 9 9 5}$ & $\mathbf{1 9 9 6}$ & $\mathbf{1 9 9 7}$ & $\mathbf{1 9 9 8}$ & $\mathbf{1 9 9 9}$ & $\mathbf{2 0 0 0}$ & $\mathbf{2 0 0 1}$ \\
\hline Belgium & 10,721 & 11,020 & 11,655 & 11,561 & 11,538 & 12,085 & 12,551 & 12,885 \\
Denmark & 13,026 & 13,188 & 13,606 & 13,881 & 14,189 & 14,658 & 15,107 & 15,428 \\
Germany & 12,005 & 11,903 & 12,749 & 12,925 & 12,561 & 12,859 & 13,506 & 14,108 \\
Greece & 4,094 & 4,371 & 4,646 & 5,009 & 5,401 & 5,317 & 5,766 & 5,829 \\
Spain & 5,320 & 5,200 & 5,335 & 5,635 & 5,812 & 6,267 & 6,762 & 7,309 \\
France & 10,718 & 10,717 & 11,039 & 11,324 & 11,292 & 11,564 & 11,778 & 12,146 \\
Ireland & 6,261 & 7,010 & 7,027 & 7,736 & 8,864 & 9,076 & 9,302 & 10,461 \\
Italy & 6,477 & 6,711 & 6,373 & 6,932 & 7,516 & 7,834 & 8,106 & 8,342 \\
Luxembourg & 16,441 & 16,993 & 18,034 & 18,110 & 18,270 & 19,364 & 20,042 & 20,870 \\
Netherlands & 9,984 & 10,272 & 10,962 & 11,121 & 11,136 & 11,722 & 12,052 & 12,568 \\
Austria & na & 11,982 & 12,405 & 12,018 & 11,815 & 12,264 & 12,667 & 12,760 \\
Portugal & 3,481 & 3,595 & 3,873 & 4,083 & 4,251 & 4,447 & 4,728 & 5,263 \\
Finland & na & na & 10,361 & 10,407 & 10,625 & 10,914 & 11,412 & 11,972 \\
Sweden & na & na & na & 11,772 & 12,015 & 11,753 & 12,321 & 13,690 \\
United Kingdom & 8,225 & 8,906 & 8,635 & 9,516 & 12,017 & 12,358 & 13,801 & 15,776 \\
United States & 13,349 & 13,637 & 12,938 & 14,687 & na & 16,439 & na & 24,068 \\
\hline Tominal amounts, calculated using average annual exchange rates. \\
T) ${ }^{2}$ Referring to income earned in the year previous to the survey. \\
\hline
\end{tabular}

Table A3: Adult equivalent income by country and survey year (in Euro) ${ }^{12}$

\begin{tabular}{|c|c|c|c|c|c|c|c|c|}
\hline Survey year & 1994 & 1995 & 1996 & 1997 & 1998 & 1999 & 2000 & 2001 \\
\hline Belgium & 14,351 & 14,817 & 15,684 & 15,565 & 15,595 & 16,415 & 17,184 & 17,640 \\
\hline Denmark & 16,630 & 17,407 & 18,125 & 18,602 & 19,113 & 19,852 & 20,536 & 21,015 \\
\hline Germany & 15,418 & 15,229 & 16,271 & 16,483 & 16,056 & 16,438 & 17,240 & 17,896 \\
\hline Sreece & 5,821 & 6,133 & 6,486 & 7,013 & 7,666 & 7,554 & 8,116 & 8,182 \\
\hline Spain & 7,753 & 7,603 & 7,798 & 8,195 & 8,396 & 9,026 & 9,738 & 10,480 \\
\hline France & 14,276 & 14,478 & 14,923 & 15,302 & 15,295 & 15,733 & 16,009 & 16,513 \\
\hline Ireland & 8,979 & 9,966 & 10,125 & 11,116 & 12,811 & 13,006 & 13,444 & 15,136 \\
\hline Italy & 8,972 & 9,203 & 8,676 & 9,504 & 10,368 & 10,825 & 11,246 & 11,587 \\
\hline Luxembourg & 21,885 & 22,207 & 23,760 & 23,925 & 24,167 & 25,228 & 26,208 & 27,463 \\
\hline Netherlands & 12,943 & 13,330 & 14,206 & 14,345 & 14,317 & 15,014 & 15,396 & 16,101 \\
\hline & na & 15,994 & 16,519 & 15,944 & 15,615 & 16,166 & 16,733 & 16,789 \\
\hline Portugal & 5,181 & 5,305 & 5,707 & 6,058 & 6,319 & 6,631 & 7,037 & 7,801 \\
\hline Finland & na & na & 13,433 & 13,439 & 13,768 & 14,158 & 14,820 & 15,526 \\
\hline Sweden & na & na & na & 14,807 & 15,120 & 14,855 & 15,594 & 17,331 \\
\hline United Kingdom & 10,843 & 11,786 & 11,370 & 12,559 & 15,820 & 16,121 & 18,012 & 20,636 \\
\hline United States & 17,589 & 17,900 & 16,981 & 19,287 & na & 21,873 & na & 31,832 \\
\hline
\end{tabular}


Table A4: Poverty incidence (in \% of individuals over the period 1993-2000)

\begin{tabular}{|c|c|c|c|c|c|c|c|c|c|c|c|c|c|c|c|c|}
\hline & \multicolumn{8}{|c|}{ Laeken (relative) poverty } & \multicolumn{8}{|c|}{ Orshanksy (absolute) poverty } \\
\hline & 1993 & 1994 & 1995 & 1996 & 1997 & 1998 & 1999 & 2000 & 1993 & 1994 & 1995 & 1996 & 1997 & 1998 & 1999 & 2000 \\
\hline Belgium & 16.7 & 15.9 & 15.3 & 14.2 & 13.8 & 12.8 & 12.9 & 13.3 & 8.4 & 7.4 & 6.0 & 6.1 & 5.9 & 5.4 & 4.8 & 3.6 \\
\hline Denmark & 10.3 & 10.2 & 9.5 & 9.3 & 11.9 & 11.1 & 11.5 & 10.8 & 4.1 & 3.3 & 3.3 & 3.2 & 3.6 & 3.4 & 3.2 & 3.4 \\
\hline Germany & 14.4 & 14.6 & 14.0 & 12.1 & 11.4 & 10.9 & 10.5 & 11.1 & 9.8 & 10.7 & 7.5 & 7.0 & 6.8 & 6.3 & 5.1 & 5.1 \\
\hline Greece & 23.1 & 21.5 & 21.0 & 21.5 & 20.8 & 20.5 & 19.9 & 20.5 & 25.7 & 26.3 & 27.5 & 28.1 & 26.0 & 28.2 & 25.0 & 26.1 \\
\hline Spain & 19.6 & 19.0 & 18.0 & 20.3 & 18.2 & 18.8 & 18.0 & 18.8 & 25.4 & 29.0 & 29.1 & 29.8 & 28.6 & 24.5 & 20.6 & 19.1 \\
\hline France & 16.6 & 15.4 & 15.2 & 14.9 & 14.7 & 15.2 & 15.6 & 15.4 & 12.6 & 9.4 & 8.4 & 8.8 & 8.5 & 8.0 & 7.1 & 6.5 \\
\hline Ireland & 16.8 & 18.6 & 19.5 & 19.1 & 19.2 & 18.5 & 20.1 & 21.4 & 30.1 & 25.3 & 25.3 & 20.1 & 13.7 & 13.3 & 12.6 & 10.6 \\
\hline Italy & 20.4 & 20.4 & 20.1 & 19.5 & 18.0 & 18.0 & 18.4 & 19.3 & 22.7 & 23.2 & 28.0 & 23.0 & 19.4 & 18.0 & 17.0 & 16.7 \\
\hline Luxembourg & $\mathrm{na}^{1}$ & 13.2 & 11.8 & 11.4 & 12.2 & 12.7 & 11.9 & 12.5 & na & 1.1 & 0.7 & 0.7 & 1.0 & 1.0 & 0.4 & 0.6 \\
\hline Netherlands & 10.0 & 11.3 & 11.7 & 10.5 & 10.3 & 10.7 & 10.4 & 11.3 & 7.1 & 8.6 & 8.4 & 6.1 & 6.8 & 6.8 & 5.6 & 6.6 \\
\hline Austria & na & 13.4 & 14.0 & 13.0 & 12.9 & 12.0 & 11.7 & 11.9 & na & 6.1 & 5.2 & 5.8 & 6.2 & 5.8 & 3.9 & 4.8 \\
\hline Portugal & 22.5 & 22.9 & 21.5 & 21.6 & 20.8 & 20.5 & 20.8 & 20.1 & 40.0 & 42.2 & 40.2 & 38.1 & 38.4 & 35.5 & 32.2 & 32.2 \\
\hline Finland & na & na & 8.1 & 8.3 & 9.4 & 10.7 & 10.9 & 11.4 & na & na & 4.1 & 4.5 & 5.1 & 5.7 & 4.6 & 4.9 \\
\hline Sweden & na & na & na & 8.9 & 10.4 & 9.5 & 10.9 & 10.4 & na & na & na & 7.1 & 7.9 & 6.7 & 7.3 & 5.7 \\
\hline United Kingdom & 19.6 & 20.0 & 19.5 & 17.8 & 19.0 & 19.4 & 18.7 & 17.1 & 17.6 & 15.8 & 15.2 & 11.4 & 12.0 & 13.1 & 10.7 & 9.3 \\
\hline United States & 24.0 & 24.0 & 23.8 & 21.7 & na & 25.4 & na & 23.5 & 12.4 & 11.4 & 10.6 & 8.5 & na & 13.0 & na & 8.7 \\
\hline
\end{tabular}


Table A5: Population shares by age groups in 2000

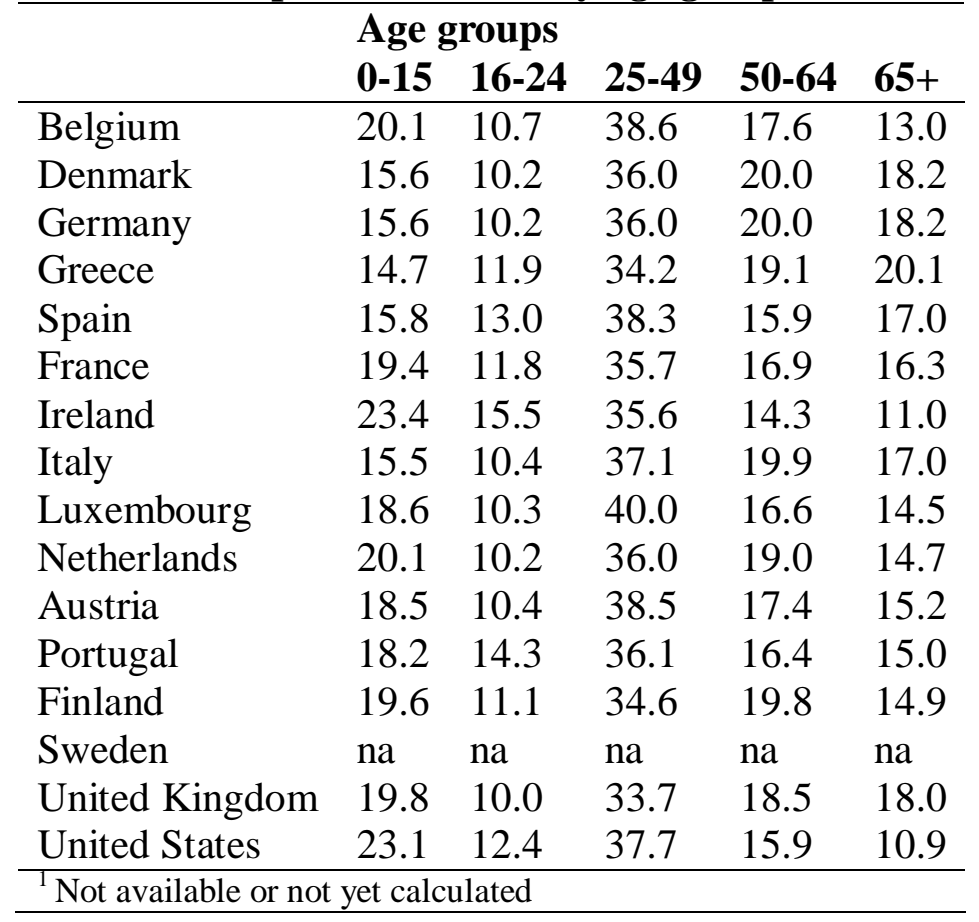


Table A6: Population shares by household type in 2000

\begin{tabular}{|c|c|c|c|c|c|c|c|c|c|}
\hline & 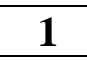 & & & & & & & & \\
\hline enm & .0 & 3.9 & & 5.6 & 1.8 & 9.4 & & 4.4 & \\
\hline & & & & & & & & & .0 \\
\hline & & U & .6 & 6 & 0 & U & & & 5.1 \\
\hline & & 6 & & & & 8.9 & & & .5 \\
\hline & & & & & & & & J & 16.0 \\
\hline & & & & & & & & & \\
\hline & & & & & & & & & 16.6 \\
\hline & & 9 & & & 3 & & & & 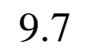 \\
\hline & & .4 & 0 & J & 4 & & & & .3 \\
\hline & & & & & & & & & \\
\hline & & & & & & & & & 0. \\
\hline & & & 9.4 & & 1.8 & & & 7 & 16. \\
\hline & & 1 & 3 & & 5 & & & .5 & ד. \\
\hline & & & & & & & & & a \\
\hline & & 13.3 & + & & & & & 3.9 & .7 \\
\hline & & 14.6 & .2 & 8.4 & 6.8 & 9.2 & 14.2 & 10.3 & 15.8 \\
\hline \multicolumn{10}{|c|}{$\begin{array}{l}1 \text { One person household } \\
2 \text { Two adults, no dependent children, both adults under } 65 \text { years } \\
3 \text { Two adults, no dependent children, at least one adult } 65 \text { years or more } \\
4 \text { Other households without dependent children } \\
5 \text { Single parent household, one or more dependent children } \\
6 \text { Two adults, one dependent child } \\
7 \text { Two adults, two dependent children } \\
8 \text { Two } 2 \text { adults, three or more dependent children } \\
9 \text { Other households with dependent children } \\
\text { or not yet calculated }\end{array}$} \\
\hline
\end{tabular}




\section{Maastricht Graduate School of Governance Working Paper Series}

\section{List of publications}

\begin{tabular}{lll}
$\begin{array}{l}2006 \\
\text { No. }\end{array}$ & Author $(s)$ & Title \\
\hline 001 & $\begin{array}{l}\text { Gassmann, F. and } \\
\text { G. Notten }\end{array}$ & $\begin{array}{l}\text { Size matters: Poverty reduction effects of means-tested and } \\
\text { universal child benefits in Russia }\end{array}$ \\
\hline 002 & $\begin{array}{l}\text { Hagen-Zanker, J. } \\
\text { and } \\
\text { M.R. Muñiz Castillo }\end{array}$ & $\begin{array}{l}\text { Exploring multi-dimensional wellbeing and remittances in } \\
\text { El Salvador }\end{array}$ \\
\hline 003 & Augsburg, B. & $\begin{array}{l}\text { Econometric evaluation of the SEWA Bank in India: } \\
\text { Applying matching techniques based on the propensity } \\
\text { score }\end{array}$ \\
\hline 004 & $\begin{array}{l}\text { Notten, G. and } \\
\text { D. de Crombrugghe ( }\end{array}$ & \begin{tabular}{l} 
Poverty and consumption smoothing in Russia \\
\hline
\end{tabular} \\
\hline
\end{tabular}

\section{7}

\begin{tabular}{|c|c|c|}
\hline No. & Author(s) & Title \\
\hline 001 & $\begin{array}{l}\text { Notten, G. and C. de } \\
\text { Neubourg }\end{array}$ & $\begin{array}{l}\text { Relative or absolute poverty in the US and EU? The battle } \\
\text { of the rates }\end{array}$ \\
\hline 002 & $\begin{array}{l}\text { Hodges, A. A. } \\
\text { Dufay, K. Dashdorj, } \\
\text { K.Y. Jong, T. } \\
\text { Mungun and U. } \\
\text { Budragchaa }\end{array}$ & $\begin{array}{l}\text { Child benefits and poverty reduction: Evidence from } \\
\text { Mongolia's Child Money Programme }\end{array}$ \\
\hline 003 & $\begin{array}{l}\text { Hagen-Zanker, J. } \\
\text { and Siegel, M. }\end{array}$ & The determinants of remittances: A review of the literature \\
\hline 004 & Notten, G. & $\begin{array}{l}\text { Managing risks: What Russian households do to smooth } \\
\text { consumption }\end{array}$ \\
\hline 005 & $\begin{array}{l}\text { Notten, G. and C. de } \\
\text { Neubourg }\end{array}$ & $\begin{array}{l}\text { Poverty in Europe and the USA: Exchanging official } \\
\text { measurement methods }\end{array}$ \\
\hline 006 & $\begin{array}{l}\text { Notten, G and C. de } \\
\text { Neubourg }\end{array}$ & $\begin{array}{l}\text { The policy relevance of absolute and relative poverty } \\
\text { headcounts: Whats in a number? }\end{array}$ \\
\hline 007 & $\begin{array}{l}\text { Hagen-Zanker, J. } \\
\text { and M. Siegel }\end{array}$ & $\begin{array}{l}\text { A critical discussion of the motivation to remit in Albania } \\
\text { and Moldova }\end{array}$ \\
\hline 008 & Wu, Treena & $\begin{array}{l}\text { Types of Households most vulnerable to physical and } \\
\text { economic threats: Case studies in Aceh after the Tsunami } \\
\text { (Theme 2) }\end{array}$ \\
\hline
\end{tabular}

